\title{
Fault Rocks of the Moine Thrust Zone: Microstructures and Textures of Selected Mylonites
}

\author{
S. H. WHITE, D. J. EVANS and D.-L. ZHONG† \\ Geology Dept., Imperial College, S. Kensington, London, SW7 2BP
}

(Received July 16, 1981)

In this paper, the microstructures typifying the common mylonites found in the Moine Thrust Zone at Eriboll are presented along with $c$-axis quartz textures. Typical cataclasite microstructures are also depicted. The study revealed that the deformation and softening mechanisms in fault rocks can change with increasing shear strain. It also revealed that strain can be extremely inhomogeneous on the microscale at high shear strains. There is evidence for episodic pulses of brittle behaviour which has been associated with possible seismic behaviour within the zone. The contribution concludes by outlining the microstructural and textural features that can be used to determine the direction of shearing in a mylonite zone.

\section{INTRODUCTION}

In a preceding paper (White, 1981), a terminology was selected that described the microstructures of fault rocks. In this article, we described the microstructures and textures of the three main sequences of mylonites seen in the Moine Thrust Zone in the Eriboll area together with a cataclasite sequence.

\section{FAULT ROCKS SELECTED}

Three main rock types give rise to mylonites in the Eriboll area, they are the Lewisian gneiss, the Moine schists and the Pipe Rock quartzite. Added

† Permanent address: Academy of Science, Peking, China. 
to these is a sample of cataclased Lewisian gneiss which occurs along the Moine Thrust at Alt Odhrsgaraidh (from where the samples were collected) and also in pods along the Arnabol Thrust. The cataclased Lewisian can easily be distinguished from the equivalent mylonite because of its lack of a foliation.

\section{MYLONITISED LEWISIAN GNEISS}

\section{Microstructures}

The type locality for a mylonite can be located from Teall's (1918) account of his visit to the area with Lapworth. Massive gneiss exists to within approximately $1.5 \mathrm{~m}$ of the Arnabol thrust plane at Ben Arnabol and becomes progressively mylonitised over a narrow interval until within $0.5 \mathrm{~m}$ of the thrust a well foliated mylonite exists (locality grid reference 4604 5948). The stages in the development of the sequence is shown in Figure 1 with finer details of the microstructures shown in Figure 2.

The initial grain refinement of the plagioclase and alkali feldspar is by cataclasis with the development of fine grained secondary minerals, viz. chlorite, mica, epidote, plagioclase and quartz in the finely cataclased areas by neomineralization. Some of the plagioclase is reduced by recrystallization. The quartz recrystallizes to a fine-grained aggregate. Because of the large percentage of feldspars, the first fault rock formed is a protocataclasite (Figure 1a). It does not have a foliation but it does contain narrow bands of fine grained quartz, plagioclase, chlorite and mica and which also have fragments of plagioclase and alkali feldspar (Figure 1b). The bands are parallel to the mylonite foliation and are c-planes as described by Berthe et al. (1979). The continual development of these. The continuing fracturing of the feldspars, with subsequent neomineralization, and continual recrystallization of the quartz leads to the development of a foliated and lineated rock with pods of fractured feldspars, a blastomylonite (Figure 1c), and then a mylonite (Figure 1d), and finally a narrow band $(2-3 \mathrm{~cm}$ thick) of ultramylonite, in which no traces of the feldspars remain (Figure 1e), along the thrust. Each fault rock type will be described in a little more detail below.

Protocataclasite At this stage the plagioclase grains show evidence for internal deformation - the twins are often bent (Figure 2a) and undulatory extinction is common. There is minor sub-grain formation and a little recrystallization. The twins often terminate sharply within grains, indicating that they are deformation twins (discussed in White, 1975). The most obvious feature is the fracturing of the feldspar grains and the separation of the fractured fragments across tensile fractures which are mainly approximately 


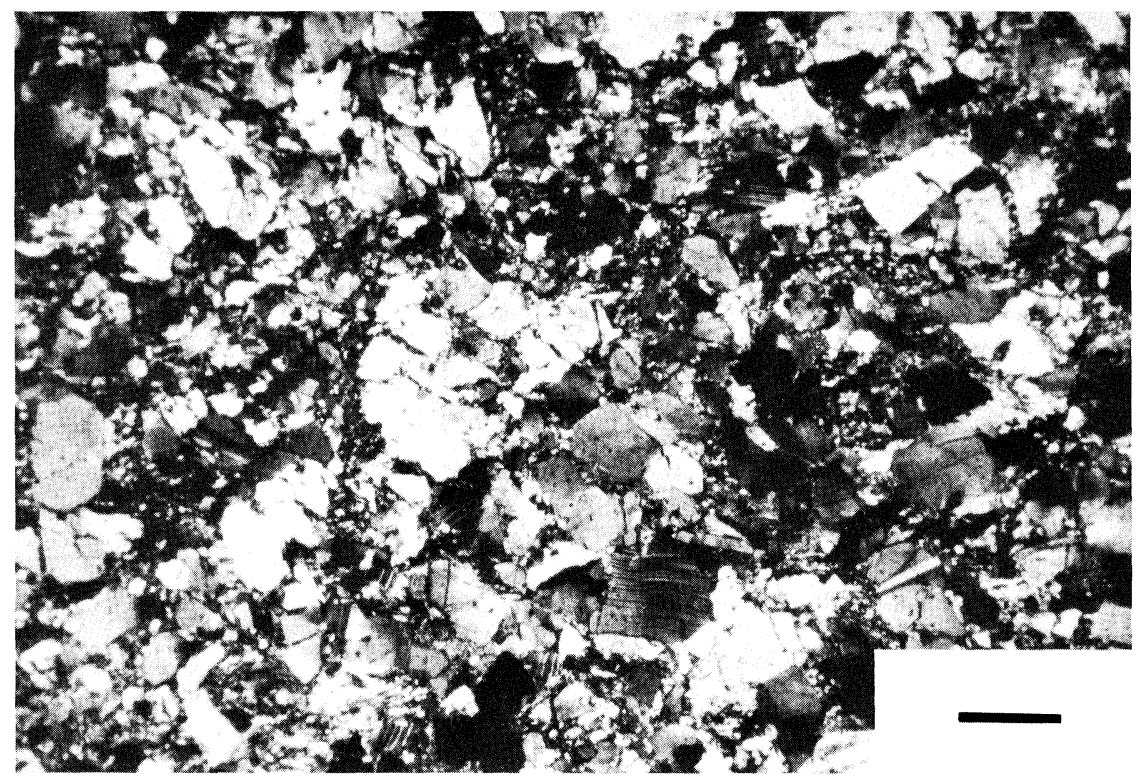

FIGURE 1 Progressive fault rock development in the Lewisian gneiss from Lapworth's type locality. The bar scale in each micrograph is equal to $1 \mathrm{~mm}$.

a) Protocataclasite. The rock consists mainly of broken feldspars in a non-foliated matrix of recrystallized quartz and secondary minerals.

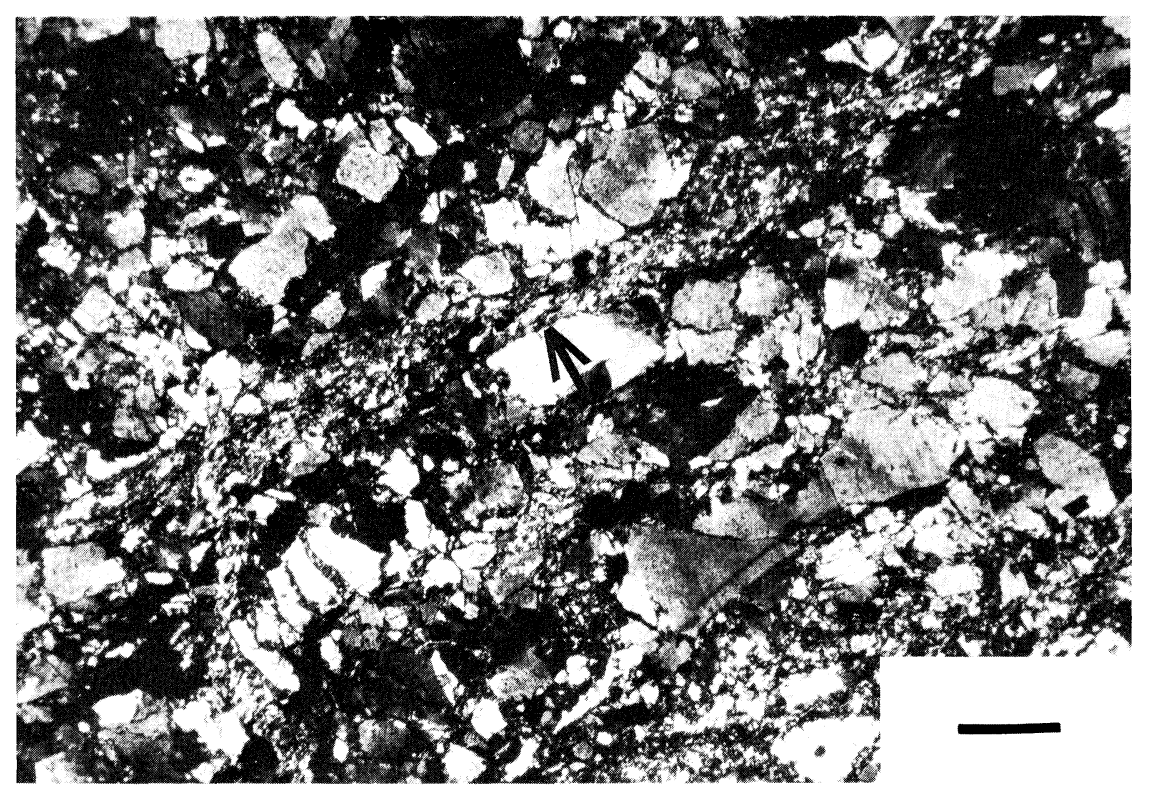

b) A c-plane (arrowed) in a protocataclasite. Note the pulled apart feldspar grain adjacent to the c-plane in the bottom left corner. 


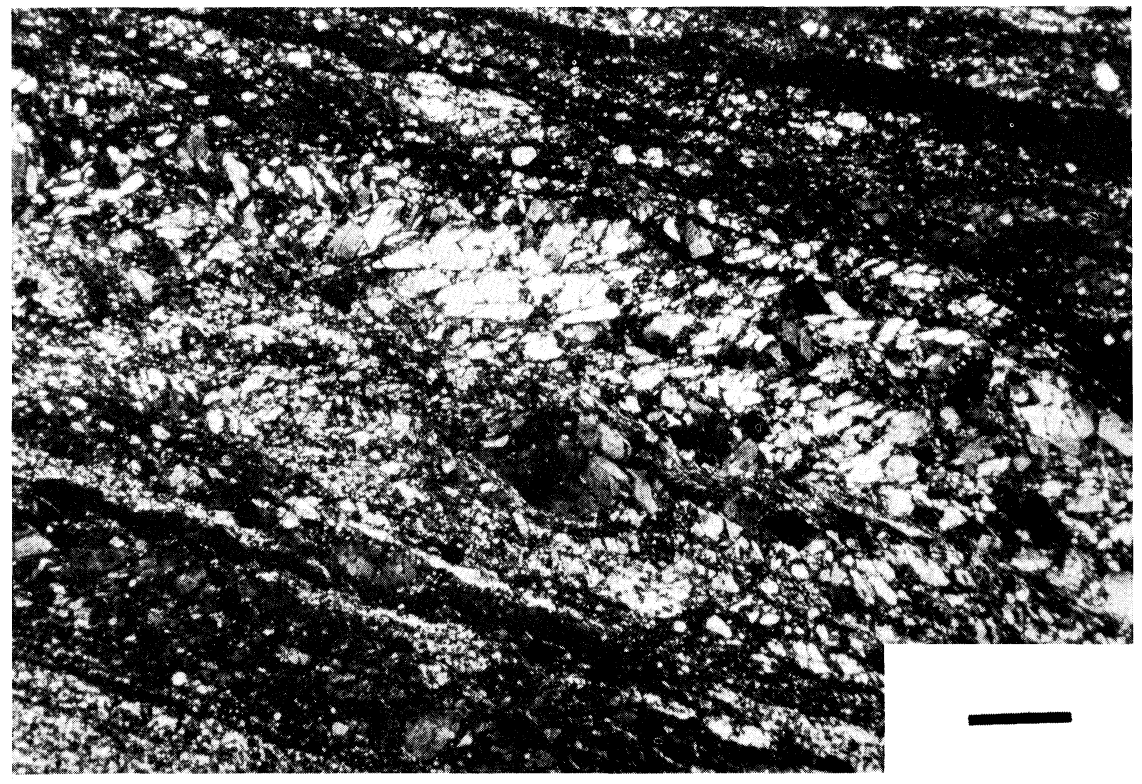

c) Blastomylonite. The rock now has a well developed foliation highlighted by dark bands of secondary muscovite, chlorite and epidote. The fragments of feldspars have been reduced in size and smeared out.

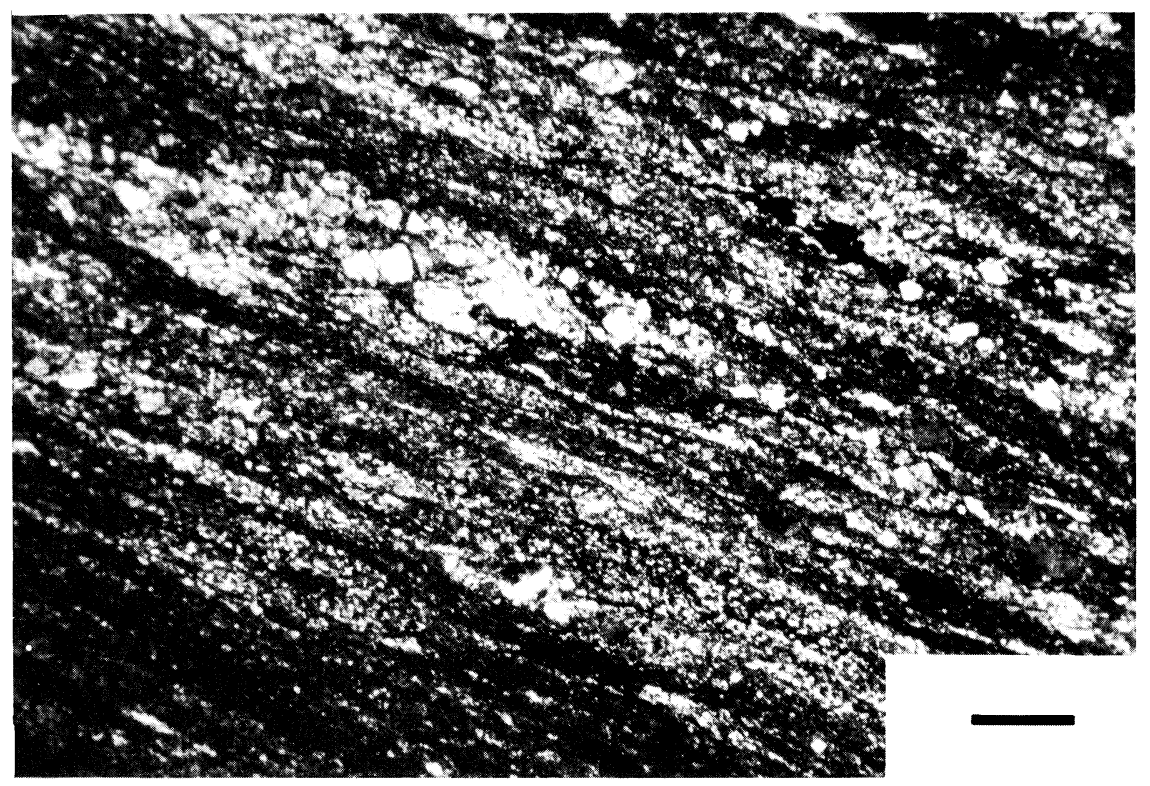

d) Mylonite. There has been a marked reduction in the amount of fragmented feldspar and an increase in quartz and secondary minerals. 


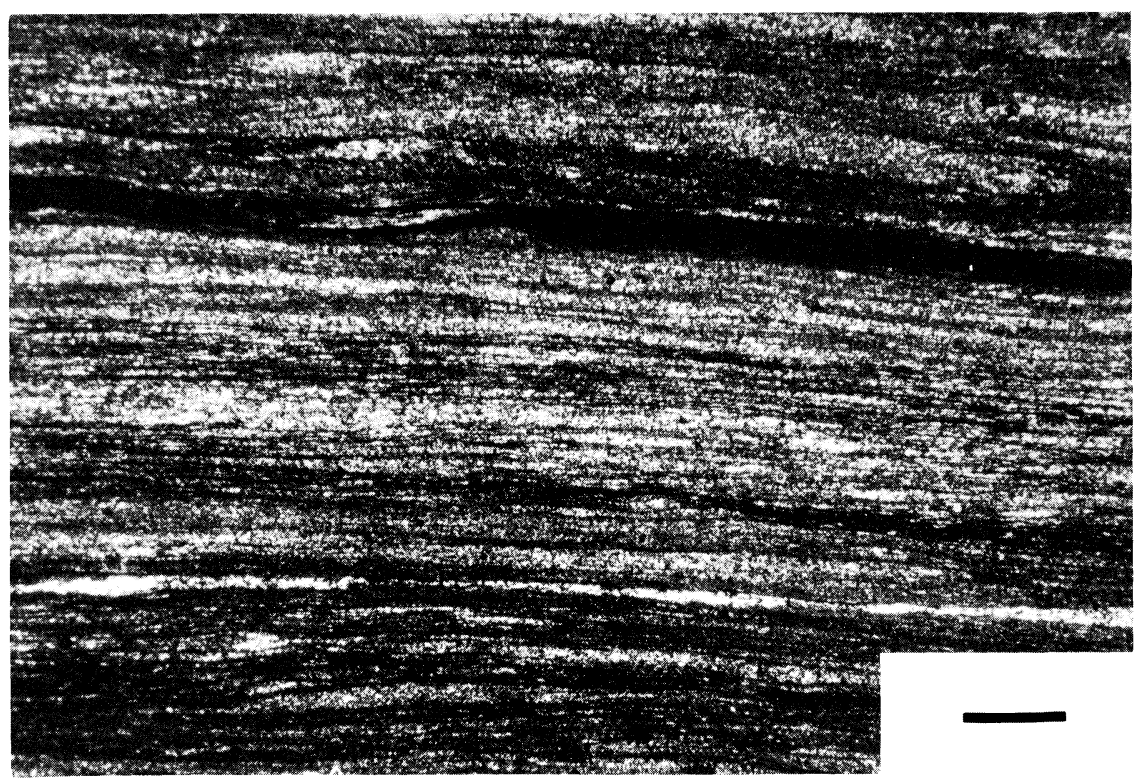

e) Ultramylonite. No feldspar fragments persist. The rock comprises of dark bands of muscovite and chlorite and light bands of quartz.

at right angles to the c-bands (Figure $1 \mathrm{~b}$ and $2 \mathrm{~b}$ ). The tensile fractures are most common in tabular grains which lie with their long axis parallel to the c-bands and especially in grains which now have twins parallel or perpendicular to the fractures. Many grains have several tensile fractures which tend to divide the tabular grains into halves and quarters; the spacing between the halves often being greater than that between the quarters. Shear fractures also occur, especially in areas adjacent to c-bands (Figure 2b).

The tensile fractures, including those that do not fully transgress a grain, are infilled with fibrous quartz, chlorite, mica and epidote. The fibres develop at right angles to the fracture walls. However, in some, the fractured fragments of grains have been displaced due to subsequent interference with adjacent grains. Such fragments are joined by oblique fibres which mimic the local movement direction. The alkali feldspars behave in a similar manner but show little evidence for internal deformation prior to fracturing.

The quartz behaves in a ductile manner and exhibits undulatory extinction; deformation bands and sub-grains (Figure 2a). The old grains have extensively recrystallized; the size of the grains being the same as the sub-grains suggesting that nucleation was by sub-grain rotation (White, 1976) rather than by bulging. The recrystallization was syntectonic as the new grains exhibit optical strain features. 


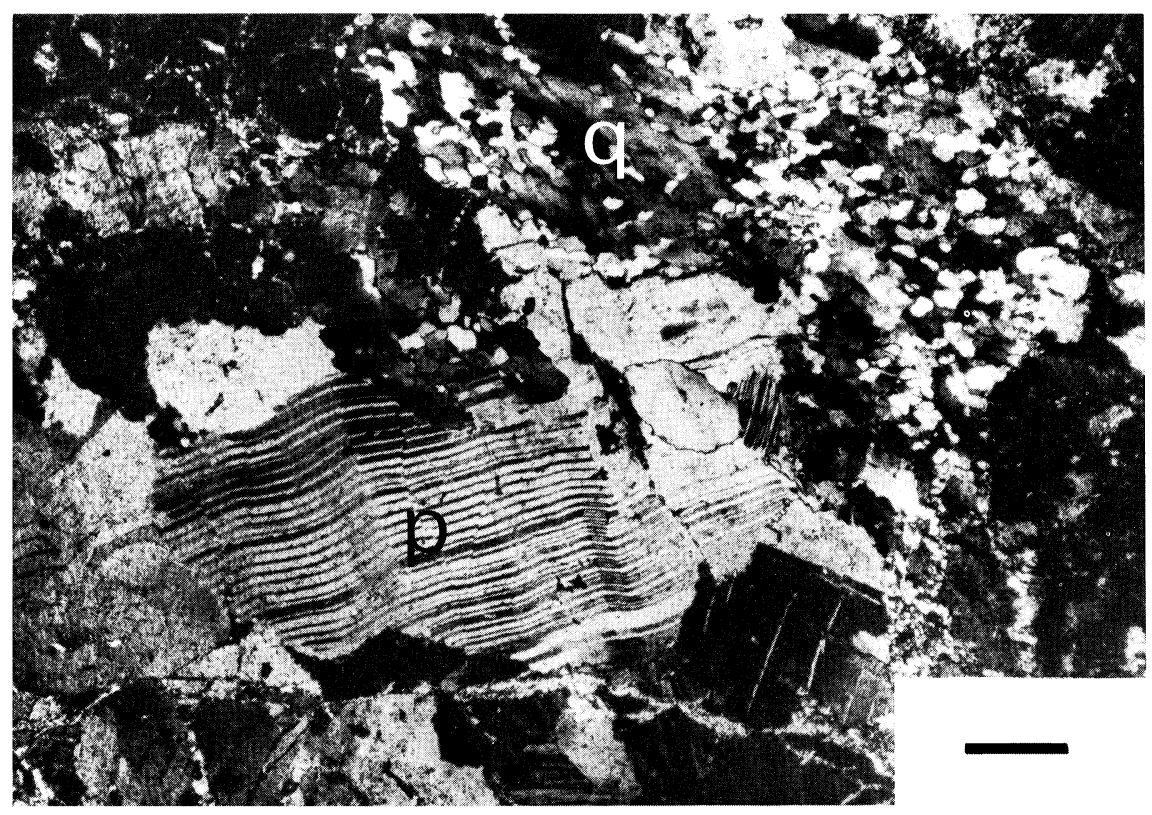

FIGURE 2 Detailed features in the Lewisian gneiss fault rock sequence.

a) Details at the protocataclasite stage. a plagioclase grain (p) with bent twin lamellae and partially recrystallized quartz grains with sub-grains (q) are shown. Bar scale represents $0.4 \mathrm{~mm}$.

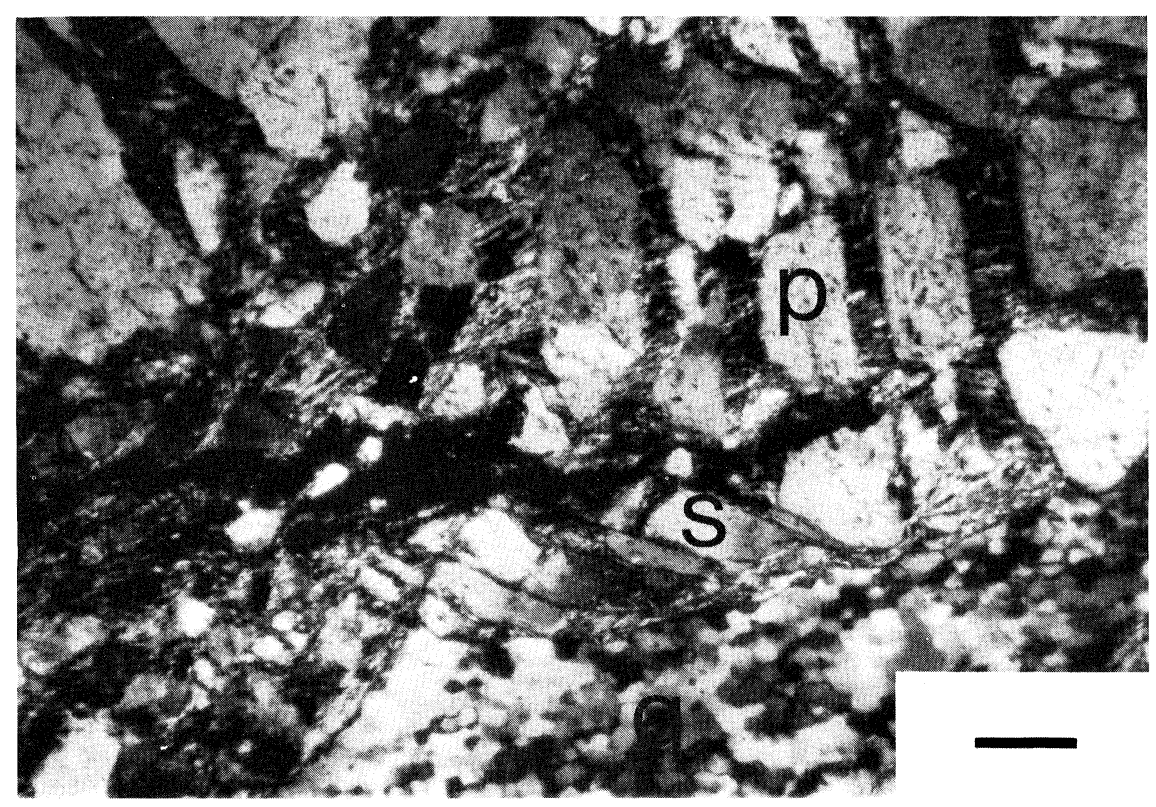

b) Pulled apart (p) and shear fractured (s) feldspars in a blastomylonite. Recrystallized quartz is seen at $\mathrm{q}$. The infilling between the tensile fractures is mainly by muscovite and chlorite. Bar scale represents $0.4 \mathrm{~mm}$. 


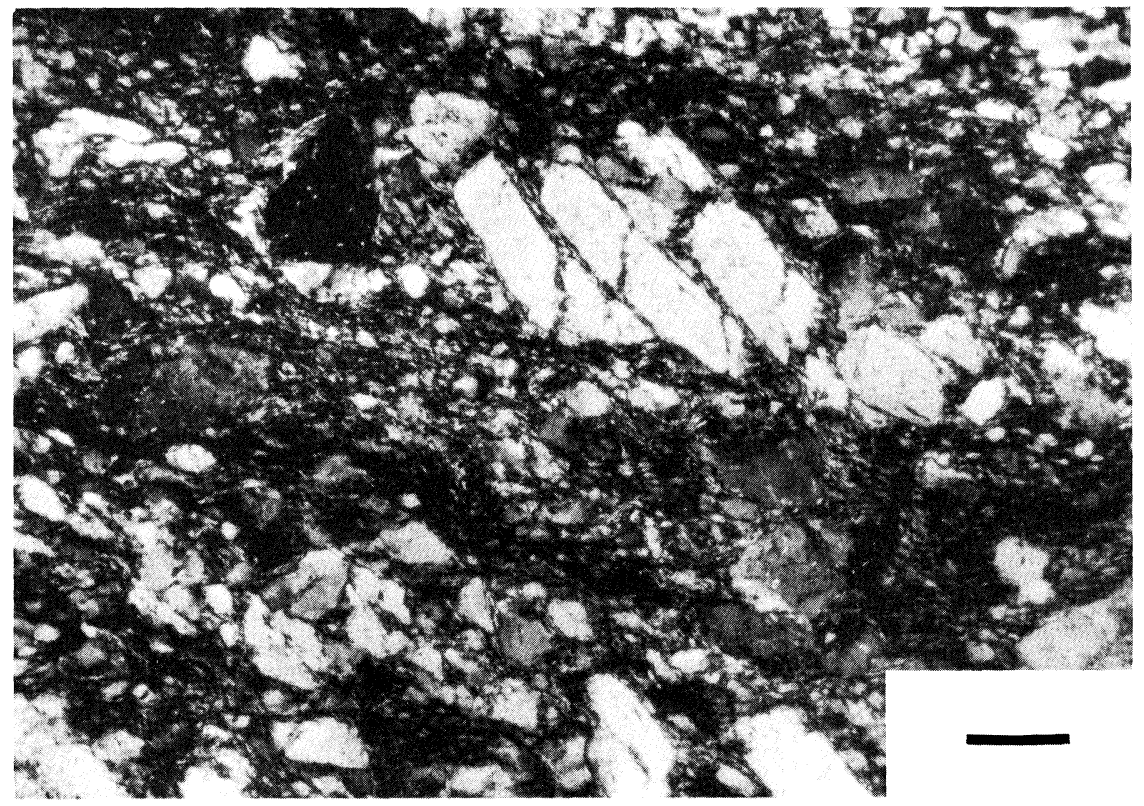

c) Shear fractures in a feldspar grain in a mylonite. Note the thin film of fine grained minerals along the fracture. Bar scale represents $0.4 \mathrm{~mm}$.

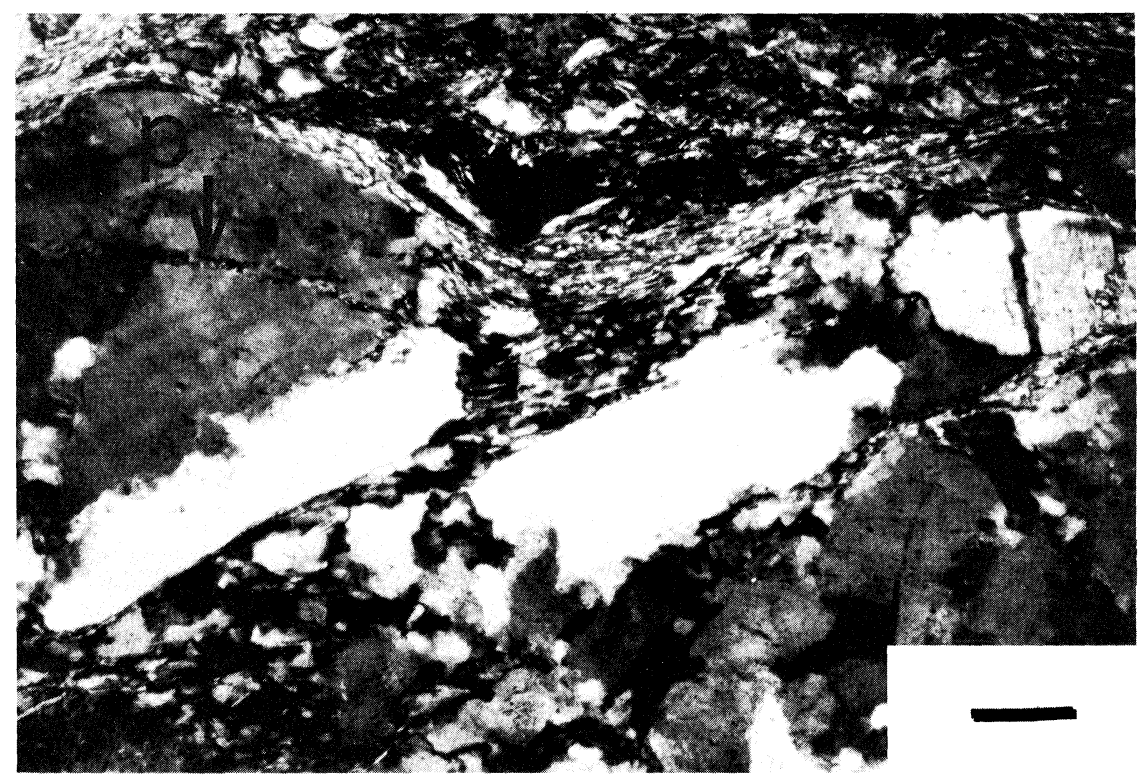

d) Detail of minerals associated with the shear fractures in a plagioclase grain. The minerals that form are platy muscovite and chlorite, secondary quartz and recrystallized plagioclase. Note the band of recrystallized plagioclase ( $\mathrm{p}$ ) within the old plagioclase grain. Bar scale represents $0.1 \mathrm{~mm}$ 
Blastomylonites As the result of the generation of more matrix, particularly due to the more extensive development of c-bands, the rock has developed an anastomosing foliation which is marked by bands of fine grained matrix and emphasised by the dimensional orientation of the phyllosilicates and elongated pods of recrystallized quartz. The feldspar clasts are much more broken up and the fragments are smaller than those in the protocataclasite. The fine grained recrystallized quartz and plagioclase in the matrix remain equidimensional. The recrystallized quartz grainsize is noteably smaller than it is in the protocataclasite.

Shear fractures, as well as tensile fractures are now prominent in the feldspars especially in the plagioclase grains (Figure 2c). The shear fractures do not have the wide infills that characterize tensile fractures. They are marked by a narrow zone of fine-grained, recrystallized plagioclase along with smaller amounts of fine grained mica, chlorite and epidote. The quartz infilling the tensile fractures, which are much more frequent than in the protocataclasite, shows evidence for deformation, viz. undulatory extinction and deformation bands, with many of the quartz fibres having recrystallized.

Individual feldspar clasts, now marked by fragments and a fine grained matrix of secondary minerals have been stretched into long strands which mark the augen visible in hand specimen (Figure 1c). Many of these strands arise from a single grain as evidenced by the twin pattern in the fragments. The strands are sandwiched between bands of recrystallized quartz, the individual grains showing evidence of deformation, viz. undulatory extinction, deformation bands and sub-grains. No old quartz grains remain. Although the percentage of chlorite, mica and, to a lesser extent, epidote increased relative to total feldspar, the individual fragments of feldspar are not extensively altered, the alteration being limited to grain margins or fractures. Intra-granular recrystallization along deformation bands is frequently seen in plagioclase grains (Figure 2d).

Mylonite The compositional banding in the mylonite is more pronounced than in the blastomylonite (Figure 1d). There is a further reduction in the size of the remaining feldspar clasts and also in the size of the recrystallized quartz grains. Most of the feldspar rich bands now consist mainly of fine grained secondary minerals with an increase in the amount of chlorite and mica but not epidote. There is extensive tensile and shear fracture development in the remaining feldspars. Feldspar fragments arising from earlier fracturing have rotated in the direction of shear for tensile fragments and against the shearing for shear fractured fragments. These then undergo further fragmentation and so on until fine equidimensional fragments form.

Ultramylonite The ultramylonite consists of alternating bands of fine 


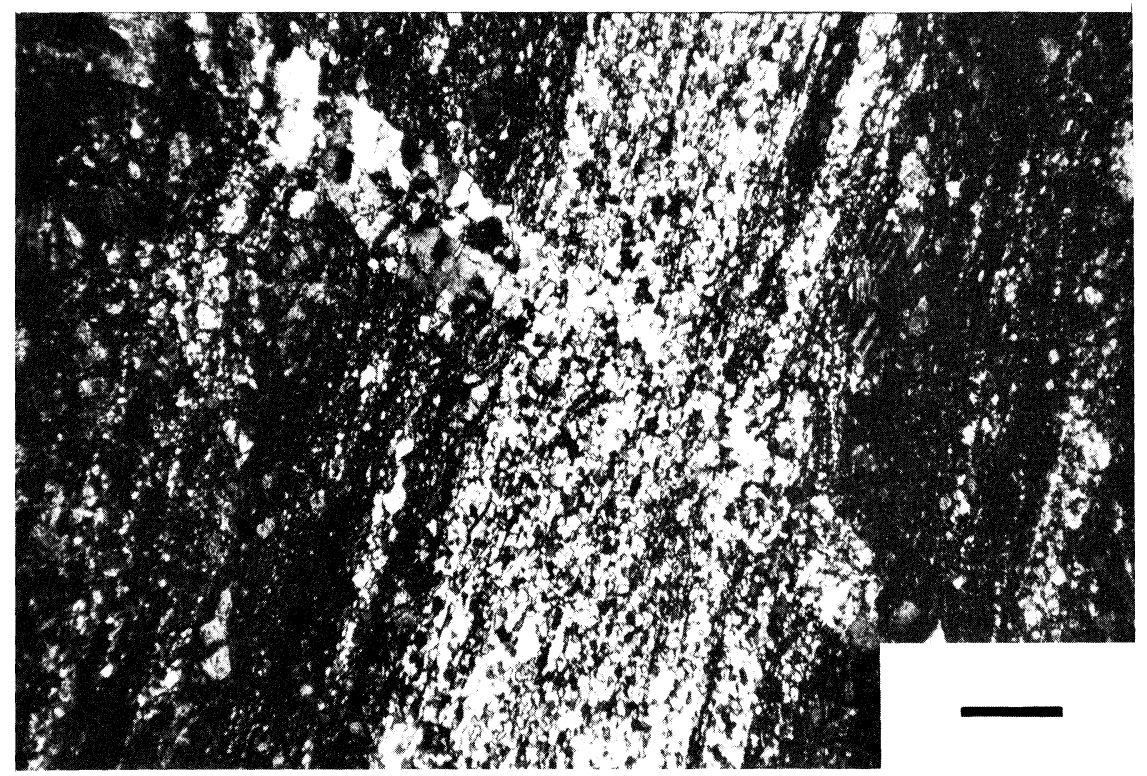

FIGURE 3 Veins in Lewisian mylonites. Bar scales represent $0.4 \mathrm{~mm}$.

a) A quartz vein cutting across the foliation in a mylonite. As a result of recrystallization, the vein becomes almost indistinguishable from the grains in the light-coloured quartz band.

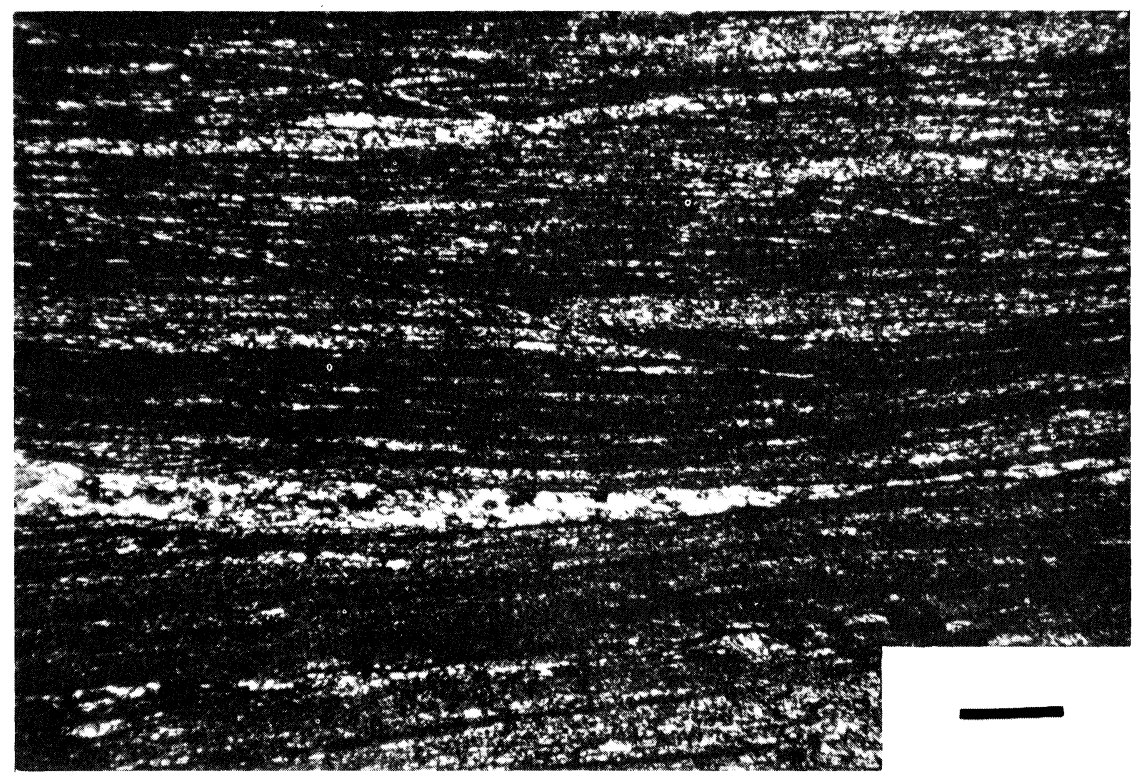

b) A quartz vein being sheared out in a dark ultrafine-grained muscovite-rich band in an ultramylonite. 
grained quartz and ultrafine grained phyllosilicates and quartz (Figure 1e). There has been a further grain size reduction of the quartz when compared with the mylonite stage and a complete loss of feldspars. Also very little epidote remains. Opaque oxides, with shadows of fibrous quartz, and which were uncommon in the earlier stages are now abundant. Shear bands (White $e t$ al., 1980) form in the phyllosilicate-rich bands. Small intrafolial sheaf folds are now commonly encountered. These were not seen at earlier stages nor were they seen at the outcrops. However, they are common in mylonites and ultramylonites from other localities.

\section{Quartz veins}

Quartz veins are common in thin sections of the blastomylonite, and especially the mylonite and ultramylonite. In the blastomylonite most tend to be perpendicular to the foliation and are infilled with blocky quartz grains. At the mylonite stage, several generations occur. Some are similar to the above but most are inclined to the foliation and contain recrystallized quartz grains which are of a size similar to those in the quartz bands making it difficult to distinguish them in these (Figure 3a). There was a further increase in the vein numbers in the ultramylonite. Most are now inclined to the foliation, many at a low angle. These become almost parallel to the foliation in the

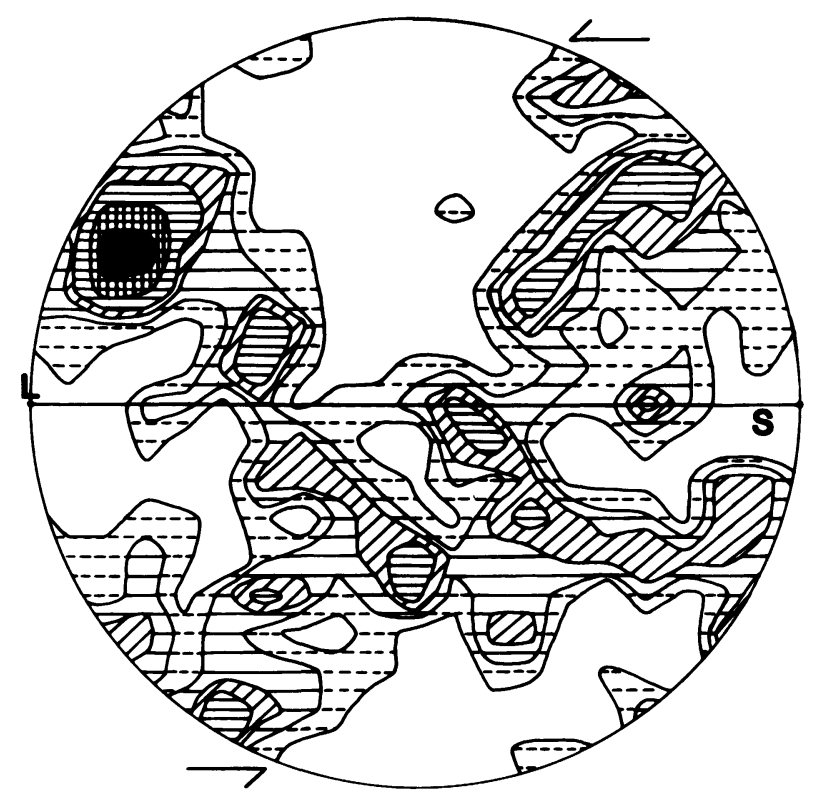

FIGURE $4 \quad C$-axis pole figure for a Lewisian mylonite. 200 grains. Contours at $0.75-1.25-1.75-$ $2.25-3.25$ and $5.25 \%$. Shear sense arrowed. $\mathrm{L}$ is the pole of the lineation and $\mathrm{S}$ is the plane of the foliation. 
very fine grained phyllosilicate bands and have been extensively stretched out in these bands (Figure $3 \mathrm{~b}$ ). Tracing them across petrographic slides reveals the extremely heterogeneous nature of the deformation in the ultramylonite, most being concentrated in the ultrafine grained phyllosilicate rich bands.

\section{Textures}

Quartz $c$-axis textures were determined with a universal stage attached to a petrological microscope. Textures were determined for the recrystallized grains at the blastomylonite and mylonite stages. The ultramylonite was too fine grained for optical textural analysis. The textures have similar patterns at both stages consisting of crossed girdles intersecting at, or in the vicinity of, the foliation plane, perpendicular to the lineation (Figure 4). Maxima normally developed near the periphery of the girdle leaning in the direction of shearing. The opening angle between the crossed girdles was symmetrical about a plane inclined to the foliation in the direction of shearing. The texture has similarities to that predicted by Lister and Hobbs (1981) to arise from dominant basal $\langle a\rangle$ and prism $\langle\mathrm{c}\rangle$ slip.

\section{MOINE MYLONITES}

\section{Microstructures}

The Moine mylonites were sampled along the Creagan Road (see Soper and Wilkinson, 1975). Collection of samples started at grid reference 44105265 and finished adjacent to the Moine Thrust at 5285 5482. In all, thirteen specimens were selected for study equi-spaced between the above two points. The mylonites in this area contain mesoscopic sheaf folds which formed synchronous with mylonitisation and are affected by late flexuring about a NE-SW axis. Although care was taken not to include mylonites affected by either in the study, some of the textures revealed bulk rotations which, as shall be discussed later, are attributed to the long range effects of the late flexures.

The microstructures of the mylonites are summarized in Figure 5. This shows progressive grain refinement, but without a change in mineralogy, as the thrust is approached. The specimen furthest from the thrust came from an area mapped as Moine schists by Soper and Wilkinson (1975). The sample, in the field, displayed a weak, NE-SW, lineation which is parallel to the former movement (slip) direction within the thrust zone. This lineation, marked by a dimensional preferred orientation of the quartz grains, occurred in all the specimens studied, becoming on the average more pronounced as the thrust was approached. 


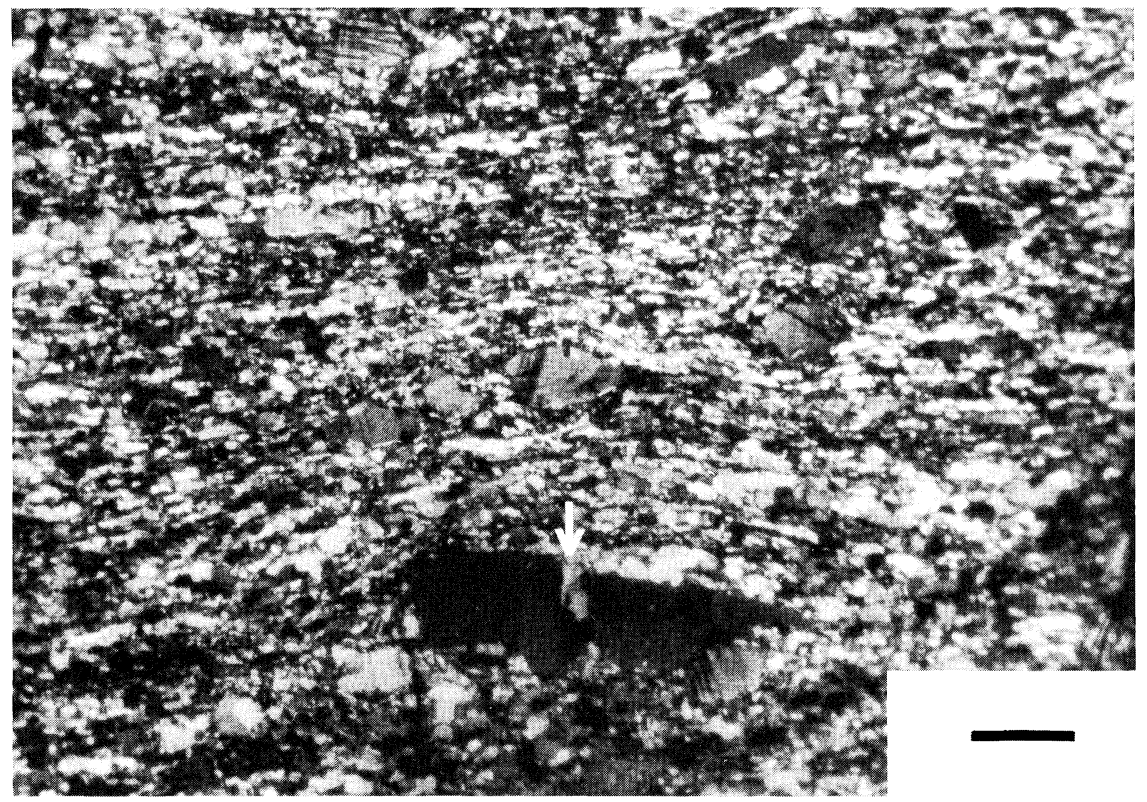

FIGURE 5 Typical microstructures in the Moine mylonites on approaching the Moine Thrust (a to d). Bar scale represents $1 \mathrm{~mm}$.

a) Coarse-grained quartz mica mylonite at the start of the traverse detailed in the text. A large fractured alkali feldspar grain is arrowed. Other alkali feldspar augens can be seen.

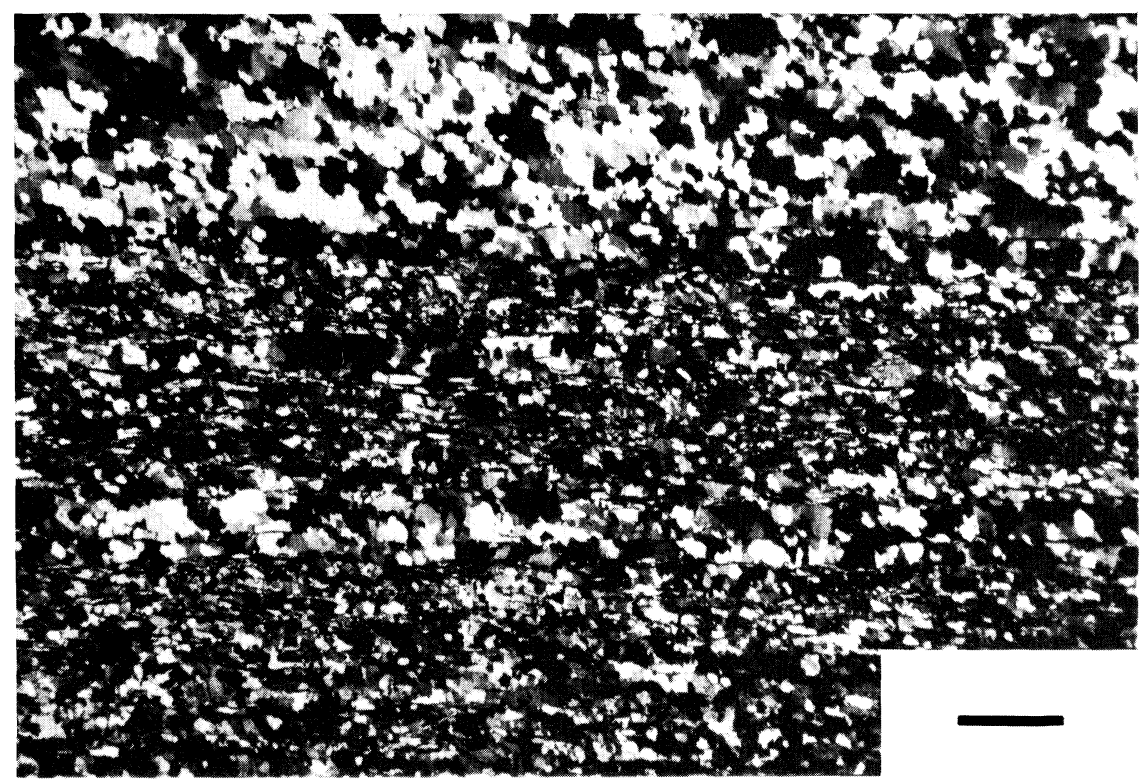

b) Coarse-grained pure quartz band and fine-grained quartz-mica bands in a mylonite halfway along the traverse. 


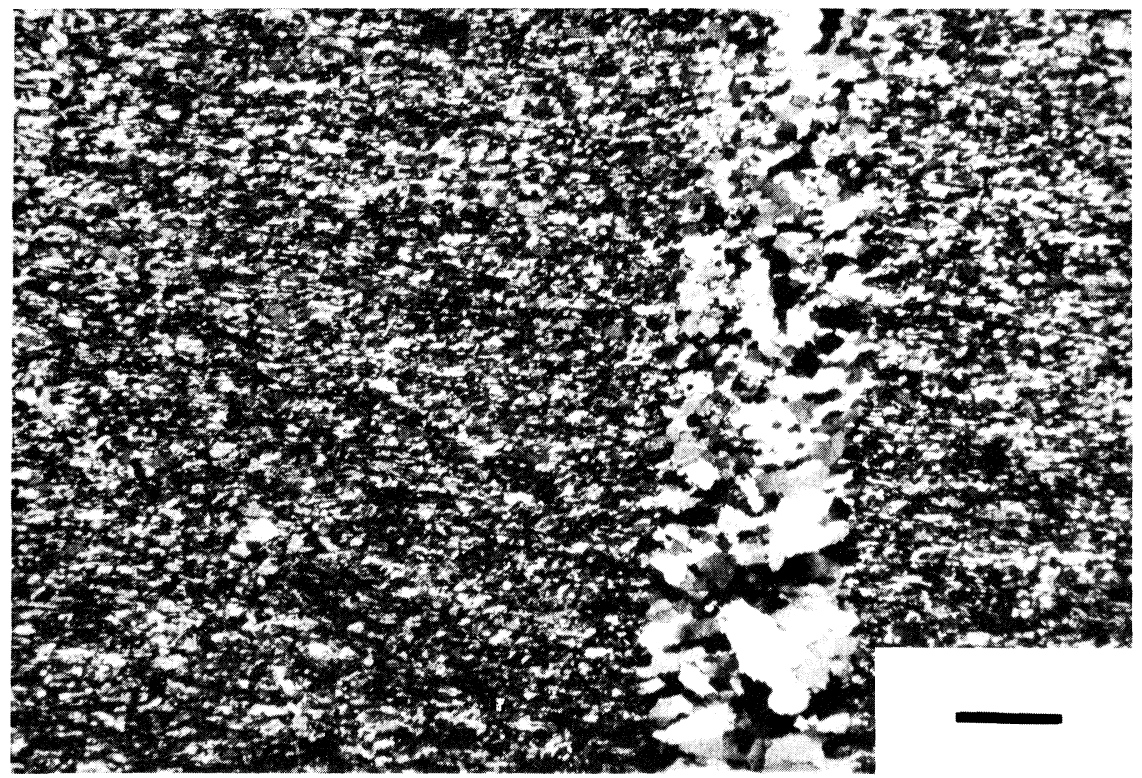

c) Fine grained mylonite with a cross cutting slightly deformed quartz vein. Collected threequarters of the way along the traverse.

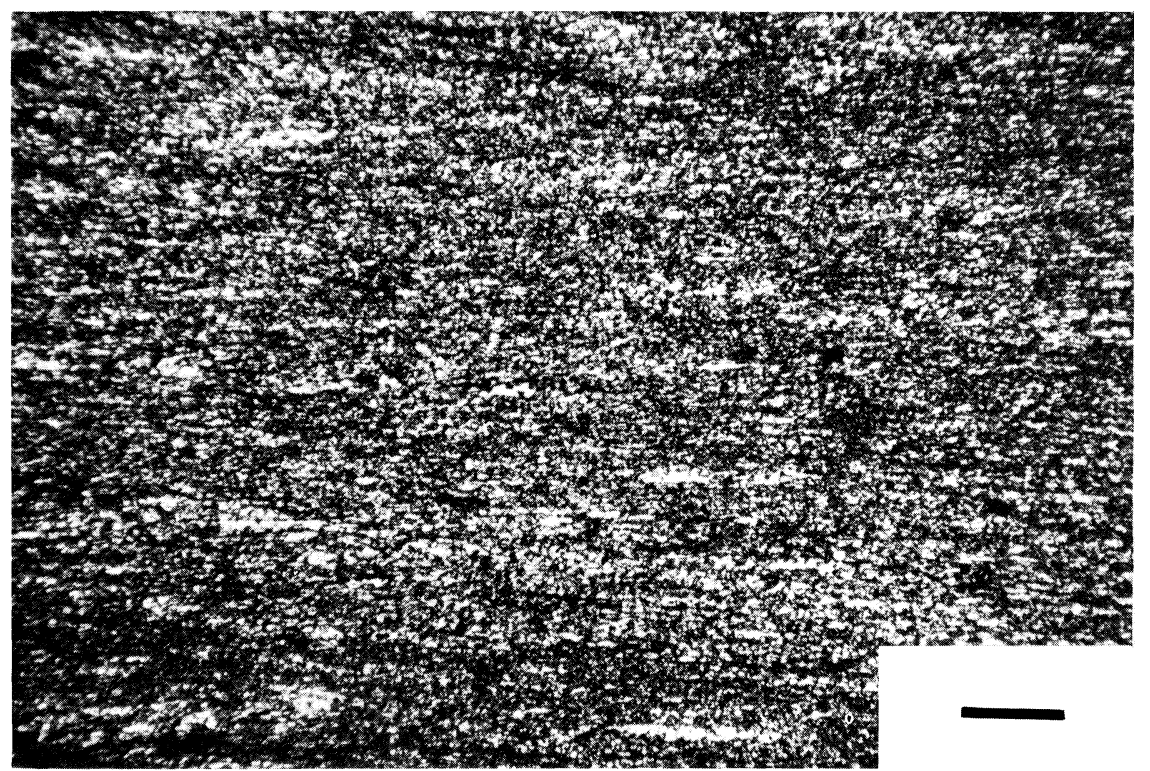

d) Finer grained mylonite adjacent to the Moine Thrust. 
All specimens consist of clasts of alkali feldspar (microcline) and plagioclase feldspar in a matrix of quartz and muscovite with the occasional band of pure quartz. The quartz grain size in the latter is greater than that in the former (Figure $5 b$ ). The presence of the bands plus the dimensional orientation of the mica give rise to the foliation. The size of all grains decrease as the thrust is approached. The presence of the alkali feldspar indicate that these are high temperature deep level mylonites. This would also explain their coarser grain size when compared with their Lewisian equivalents.

The quartz grains in all specimens were slightly elongate with the aspect ratio, especially in quartz mica bands, increasing on approach to the thrust. All quartz grains exhibited undulatory extinction, deformation bands and sub-grains especially the larger grains in the pure quartz bands. New grains developed by recrystallization at grain margins. Elongate microcline and plagioclase grains had tensile fractures, approximately perpendicular to the foliation. These broke the grains into equidimensional pieces; therefore depending upon the aspect ratios of the elongated grains there was either a single central fracture or three equi-spaced fractures dividing the grains into quarters. The tensile fractures were most common in the coarse grained samples far removed from the thrust.

Quartz veins occur in the mylonites with the number increasing as the thrust is approached. Most show little deformation apart from those in samples adjacent to the thrust. In these the quartz shows evidence for deformation. Some veins have been sheared and are cut by undeformed later ones.

The $c$-axis quartz textures of the mylonites are shown in Figure 6. It is seen that there is little variation in the texture patterns, consisting of a single girdle approximately perpendicular to the lineation but rotated towards the direction of thrusting. The girdles have a single maxima lying in, or near, the plane perpendicular to the lineation. Similar textures have been attributed to dominant prism and rhomb slip in an 〈a direction (White et al., 1979). The $a$-axis texture corresponding to similar $c$-axis patterns reveal maxima subparallel to the inferred shearing direction (Schmid et al., 1981). The sharpness of the texture and the obliquity of the girdle increase with proximity to the thrust.

Textures of both quartz-rich and of the fine-grained quartz mica bands were recorded. They show no difference in texture, see Figure 6 . The girdle in each of these samples has been rotated passively from a position perpendicular to the lineation. This has been interpreted as the effect of nearby folding. A similar rotation due to the proximity of folds was recorded in the study of the Cap de Creus quartz mylonites by Carreras et al. (1977).

The similar microstructures and textures in all samples indicates that at least part of the area mapped as a schist is a coarse grained mylonite. In 


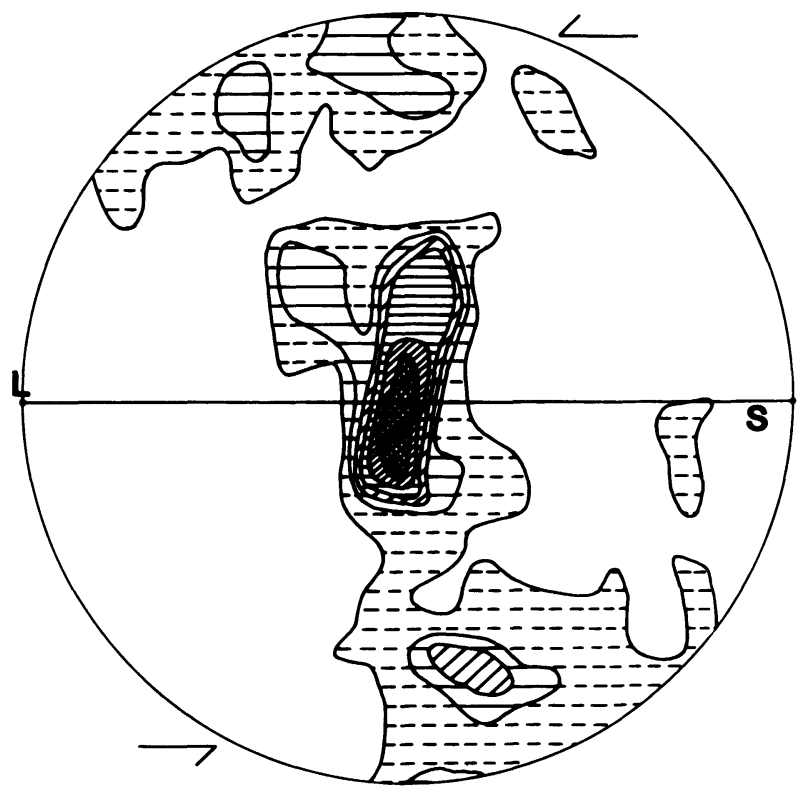

FIGURE $6 C$-axis pole figures for Moine mylonites. Arrows indicate shear sense.

a) Pole figure from area in Figure 5a. 200 grains. Contours 1-2-3-5-6\%.

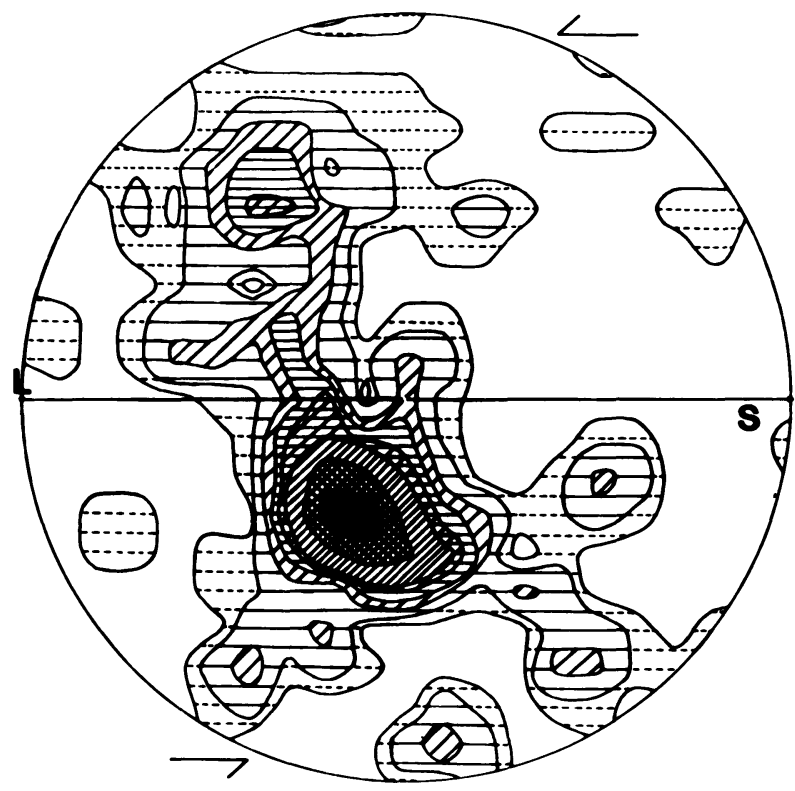

b) Pole figure for coarse quartz band in Figure 5b. 100 grains. Contours at 0.5-1.5-3.5-4.5$6.5-8-10 \%$. 


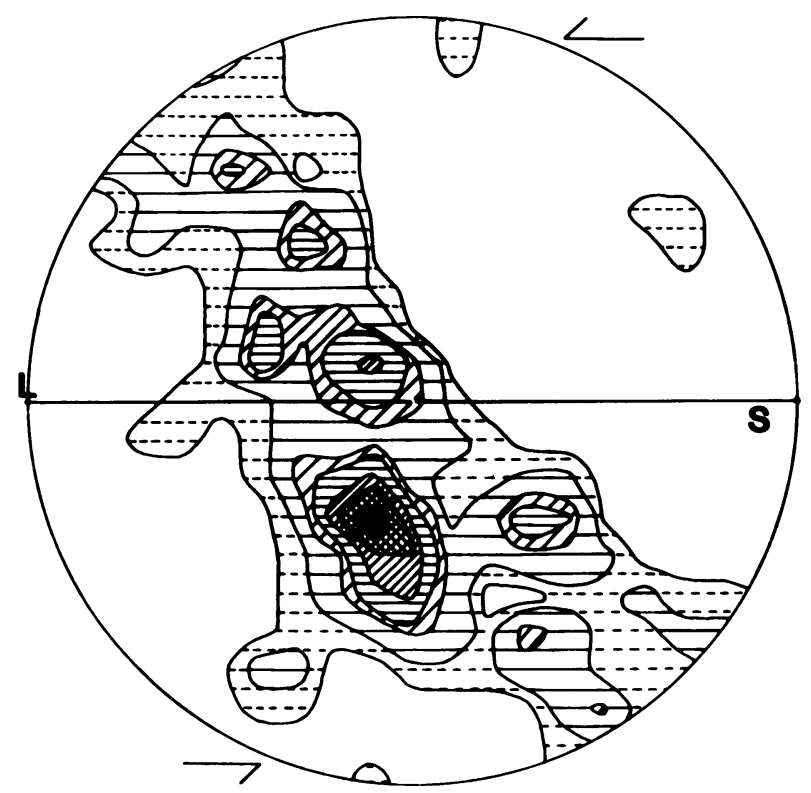

c) Fine quartz band in Figure 5b. 120 grains. Contours at 1-2-4-6-8-10-12\%.

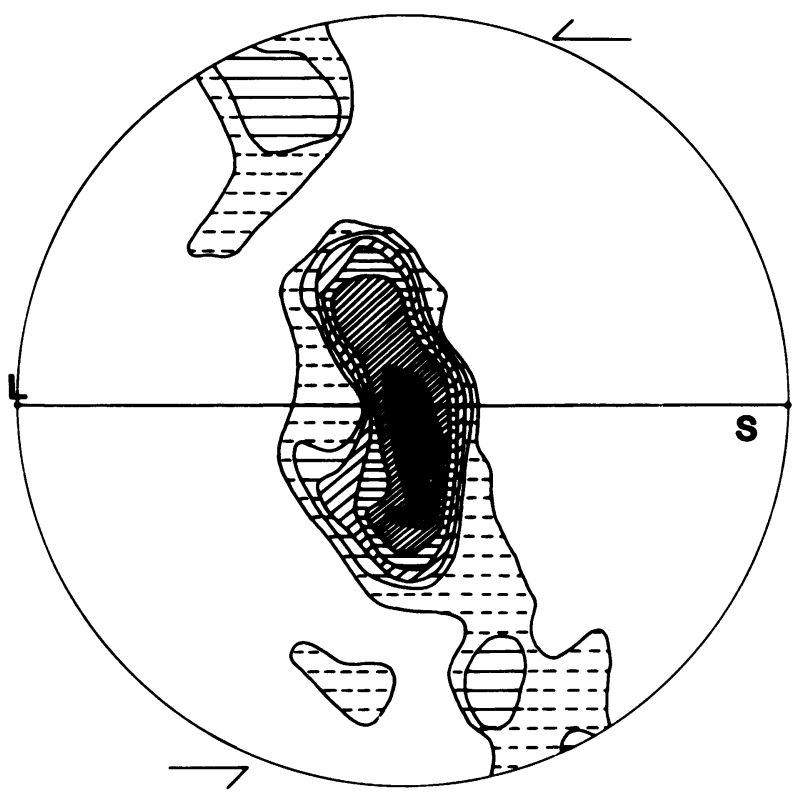

d) Pole figure for mylonite shown in Figure 5d. 200 grains. Contours $1-2-3-5-7-9-10 \%$. 
fact as no remnants of original country rock clasts were seen in any specimen; all are ultramylonites by the definitions in the preceding paper (White, 1981).

\section{PIPE ROCK MYLONITES}

\section{Microstructures}

The progressive mylonitisation of the Pipe Rock quartzite from Ben Arnabol is shown in Figure 7. The overall sequence is similar to that described by White (1979a) for mylonitisation of the same rock in small shear zones in the imbrication zone of the Heilam Nappe in the northern part of the Eriboll area.

The undeformed rock consists of rounded quartz grains in a matrix of diagenetic illites and chlorites (derived from clay minerals) and secondary quartz. There are the occasional detrital plagioclase, alkali feldspar and mica grains. Some of the quartz grains show a weak undulatory extinction which may be the effects of slight intracrystalline deformation due to the thrusting. The first unambiguous effects of the thrusting are seen in the ubiquitous presence of undulatory extinction and the development of deformation bands and sub-grains in the quartz grains. Sub-grains tend to be elongated parallel to the deformation bands in grain interiors and equidimensional at the grain edges. This is an example of the core and mantle structure described by White (1976). The degree of recrystallization differentiates the stages in progressive mylonitisation. Slight grain boundary recrystallization leads to a protomylonite then, as recrystallization progresses, to a blastomylonite, a mylonite and an ultramylonite adjacent to the thrust. There is no pronounced elongation of the quartz grains, recrystallization occurring before the grains had elongated. At the mylonite stage, lamellae of micas and chlorites develop from the breakdown of the feldspars in the starting rock and from the segregation of the diagenetic illites and chlorites. Again, a progressive decrease in matrix grain size occurs into the thrust, as do sub-grain sizes and deformation band widths in the clasts. It was also seen that sub-grain morphology and size varied within clasts. Those at the grain margins are equidimensional and smaller than the elongated ones in the central parts of grains. These observations are similar to those recorded by White (1979a).

\section{Textures}

Textural analyses were carried out on the protomylonite and the remnant old grains in the mylonite. All of the recrystallized grains at all stages were too small for texture analysis. A weak $c$-axis texture exists in the protomylonite. The mylonite has a well developed $c$-axis texture with a crossed girdle pattern (Figure 8) similar to that of the quartz grains in the Lewisian mylonite (Figure 4) but with a much smaller opening angle. The other main 


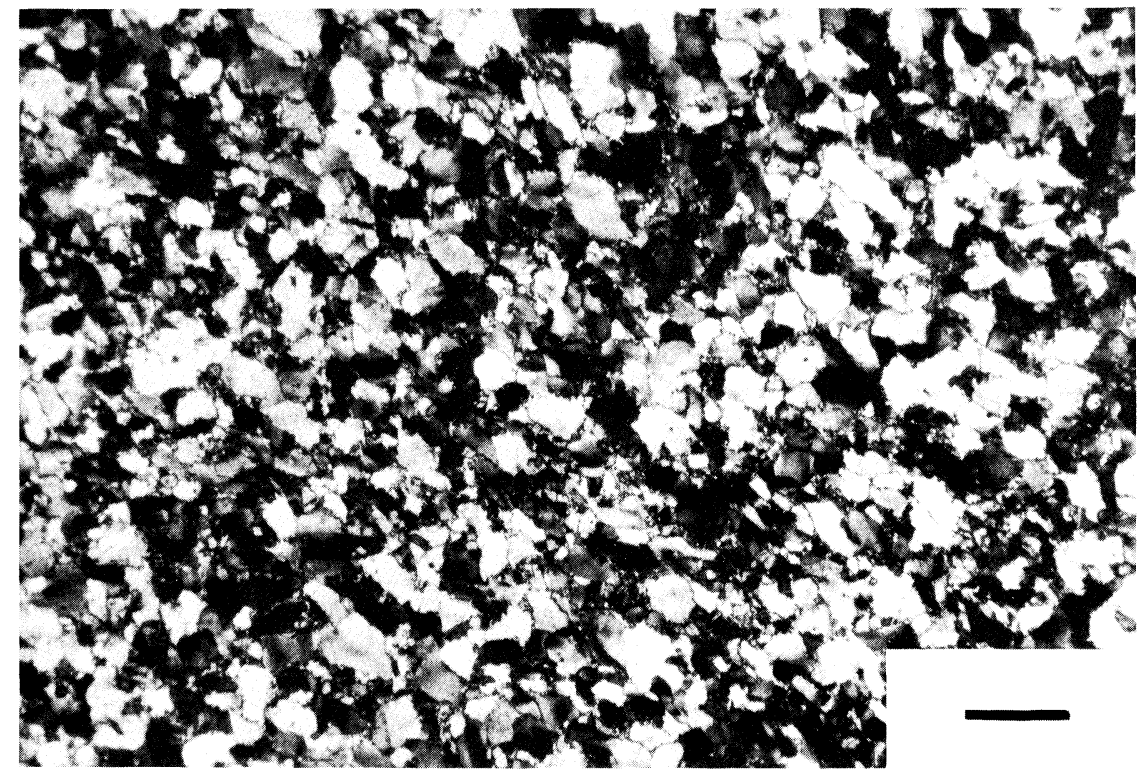

FIGURE 7 Fault rock development in the Pipe Rock.

a) Protomylonite. The quartz grains exhibit sub-grains, deformation bands and undulatory extinction. Grain boundary recrystallization has occurred. Bar scale equals $1.0 \mathrm{~mm}$

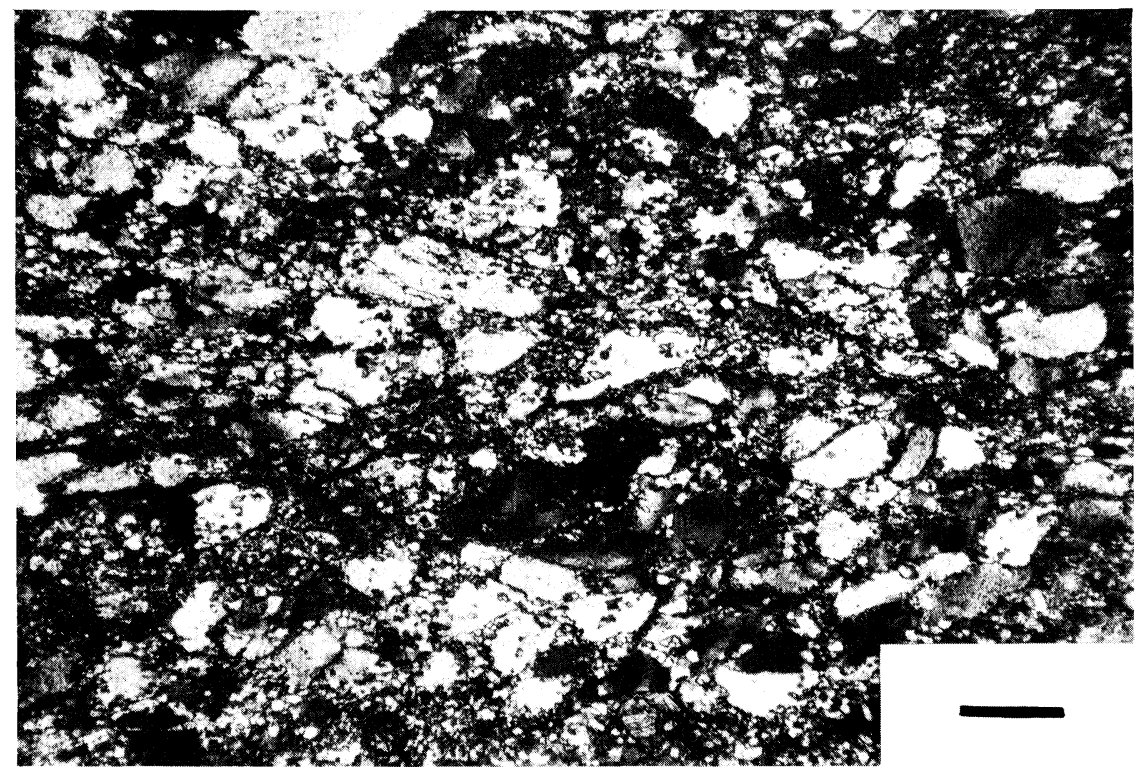

b) Blastomylonite. Grain boundary recrystallization is more advanced. Bar scale equals $0.4 \mathrm{~mm}$. 


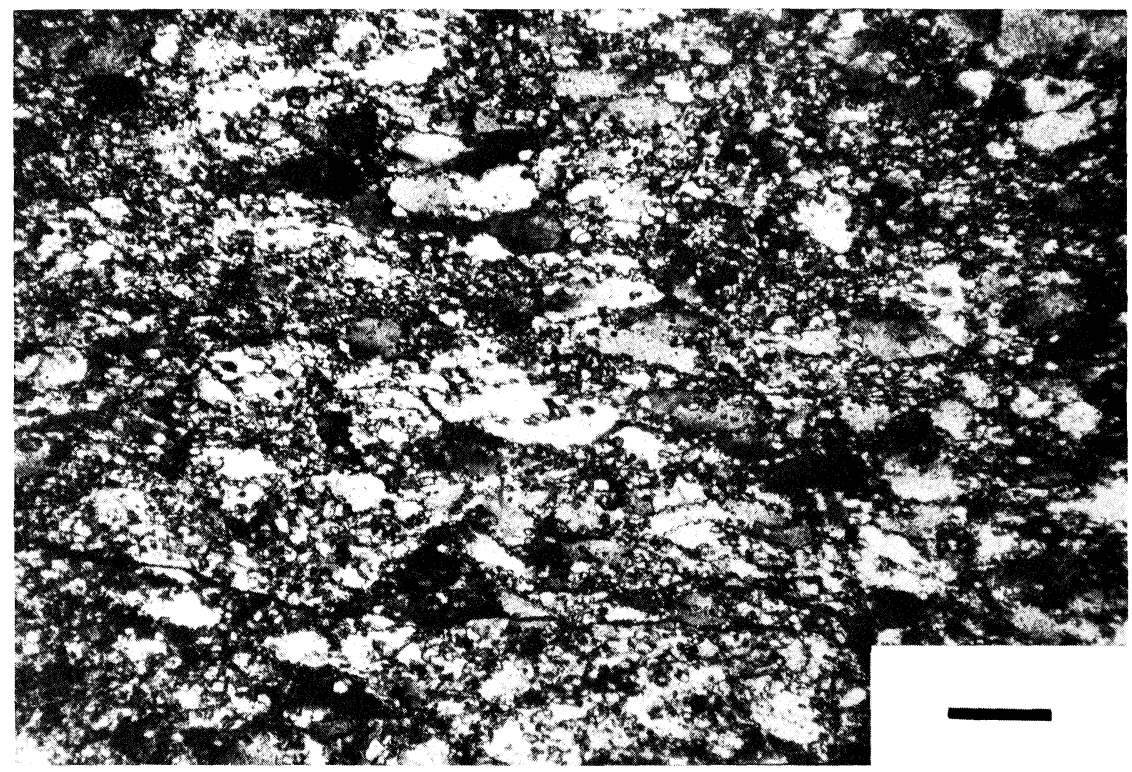

c) Mylonite. The percentage of recrystallized grains has increased and the old grains are now elongate. Bar scale equals $0.4 \mathrm{~mm}$.

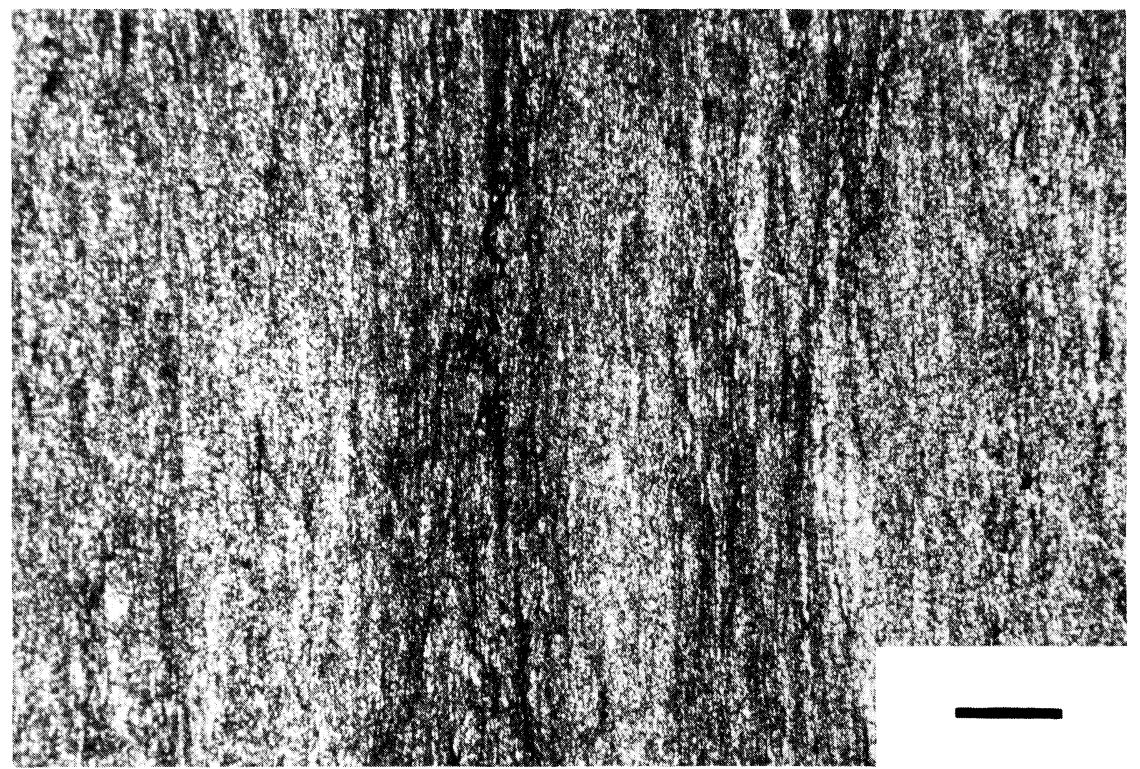

d) Ultramylonite. Recrystallization is complete. The dark bands are muscovite and chlorite rich segregations. Bar scale equals $0.4 \mathrm{~mm}$. 


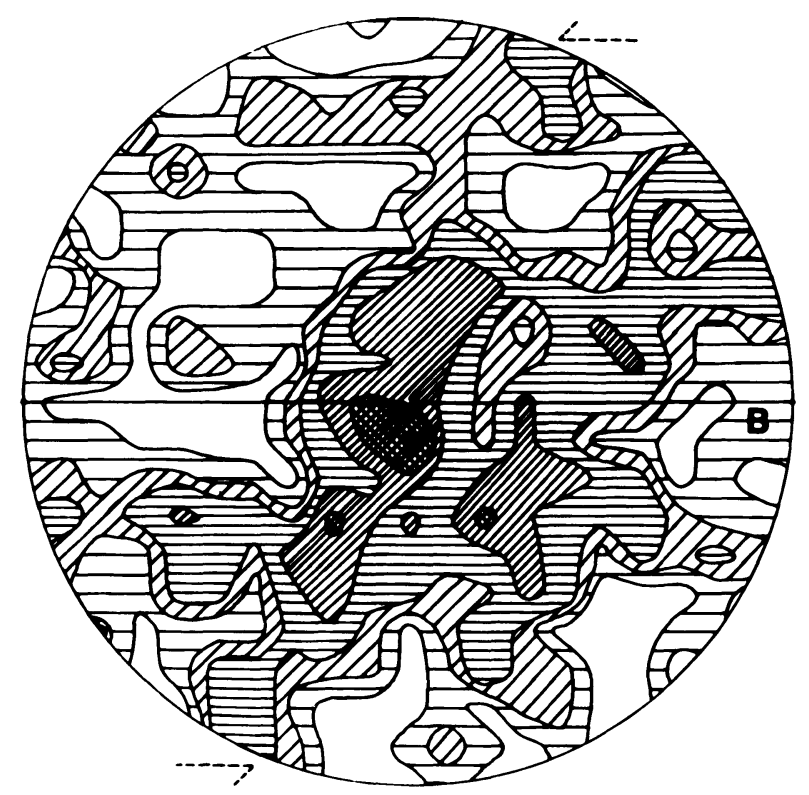

FIGURE $8 \quad C$-axis pole figures from the Pipe Rock sequence. Shear sense arrowed. a) Protomylonite, old grains. 200 grains. Contours $0.25-0.75-1.25-2.25-3.25-5.25 \%$.

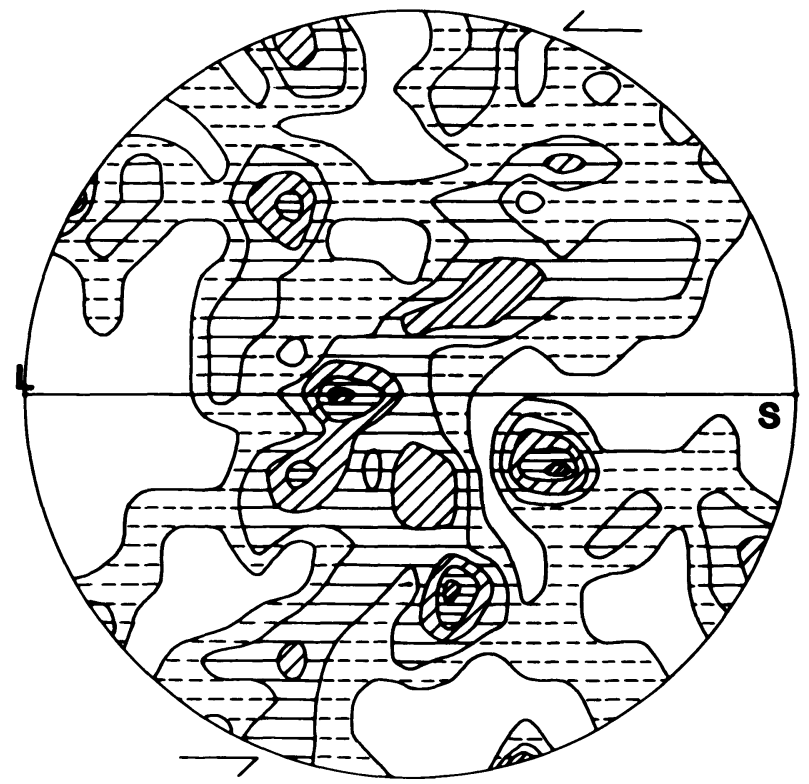

b) Mylonite, old grains. 100 grains. Contours at 0.5-1.5-2.5-2.5-3.5-4.5\%. 
differences are that the maxima are positioned away from the periphery and the girdles are more diffuse. As in the Lewisian mylonite the maxima are in the girdle leaning sympathetically with the shearing direction. The plane bisecting the opening angle between the girdles has also rotated in the direction of shearing.

\section{CATACLASITE}

The cataclastic sequence is shown in Figure 9. The sequence is very similar to that seen in Figure 1 for the Lewisian mylonites. However there is greater grain refinement by cataclasis before neomineralization occurs to form a foliation and therefore a mylonite. The main reason for this difference is the lower amount of quartz in the cataclasites. Thus instead of changing from a protocataclasite to a blastomylonite the change occurs after the blastocataclasite stage. The ultimate product is an ultramylonite similar to that seen at Lapworth's locality. The quartz undergoes recrystallization. The plagioclase and alkali feldspars all show evidence for intracrystalline deformation prior to ductile fracturing. Some grains have undergone slight recrystallization.

\section{DISCUSSION}

\section{Deformation and softening mechanisms}

The deformation and softening mechanisms in each fault rock will depend largely on its main mineral constituent. From this point of view, the Moine and Pipe Rock fault rocks will depend largely on the behaviour of quartz. The Lewisian behaviour will initially depend on feldspars and then on quartz as the mylonite and quartz plus mica as the ultramylonite are formed. Each mineral will be considered in detail below.

Quartz Quartz has behaved ductilely in all of the fault rocks studied. At low shear strains in the Pipe Rock and also in the Lewisian sequence, i.e. at the protomylonite and blastomylonite stages, the old quartz grains show internal strain features that are consistent with deformation by dislocation processes. The slow strain rates $\left(10^{-11}\right.$ to $\left.10^{-14} \mathrm{sec}^{-1}\right)$ that characterize natural deformations and the temperatures at which deformation occurred (in the above at low greenschist facies conditions indicating temperatures of around $300^{\circ} \mathrm{C}$ ) would favour dislocation creep or warm working. $\mathrm{Re}-$ crystallization was an integral part of the deformation process. Close study of the recrystallized quartz grains in all of the fault rocks studied, revealed 


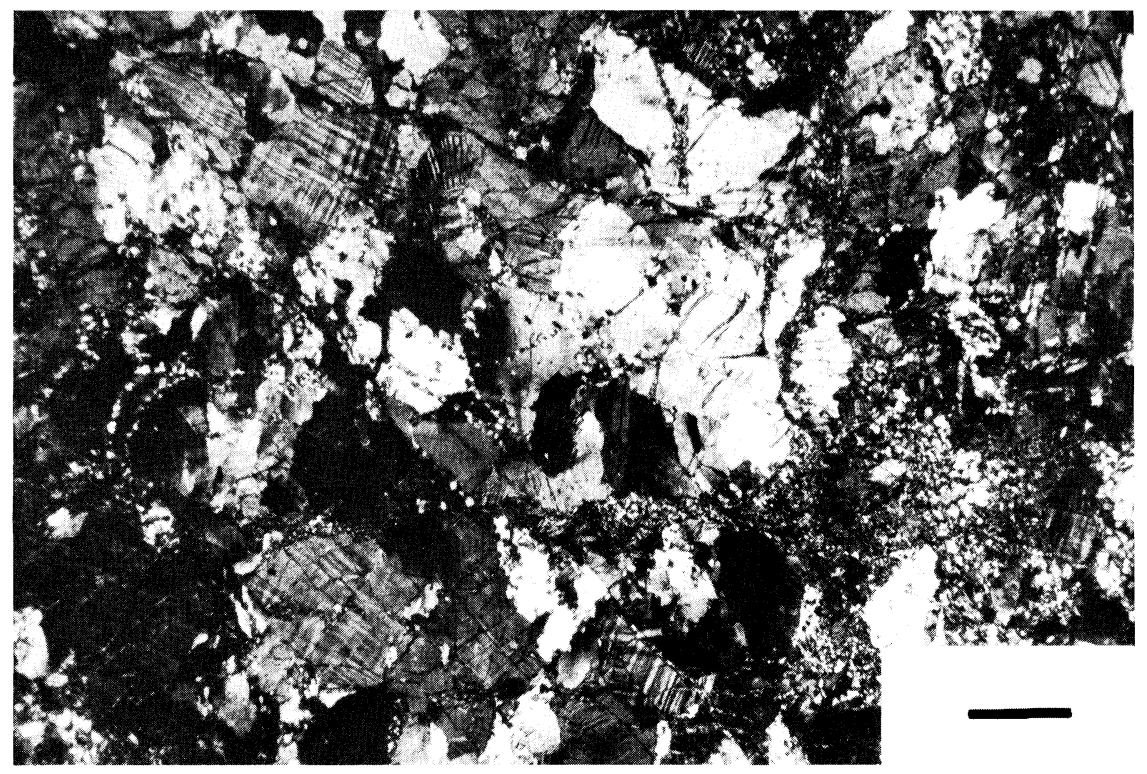

a)

FIGURE 9 Cataclasite sequence. Figures $a-c$ show the effect of increasing cataclasis in a Lewisian gneiss. Figure $a$ is the deformed gneiss prior to cataclasis which first produces a protocataclasite $(b)$ and then a blastocataclasite $(c)$. Neomineralization leads to the ultimate formation of an ultramylonite $(d)$. Bar scale represents $1.0 \mathrm{~mm}$.

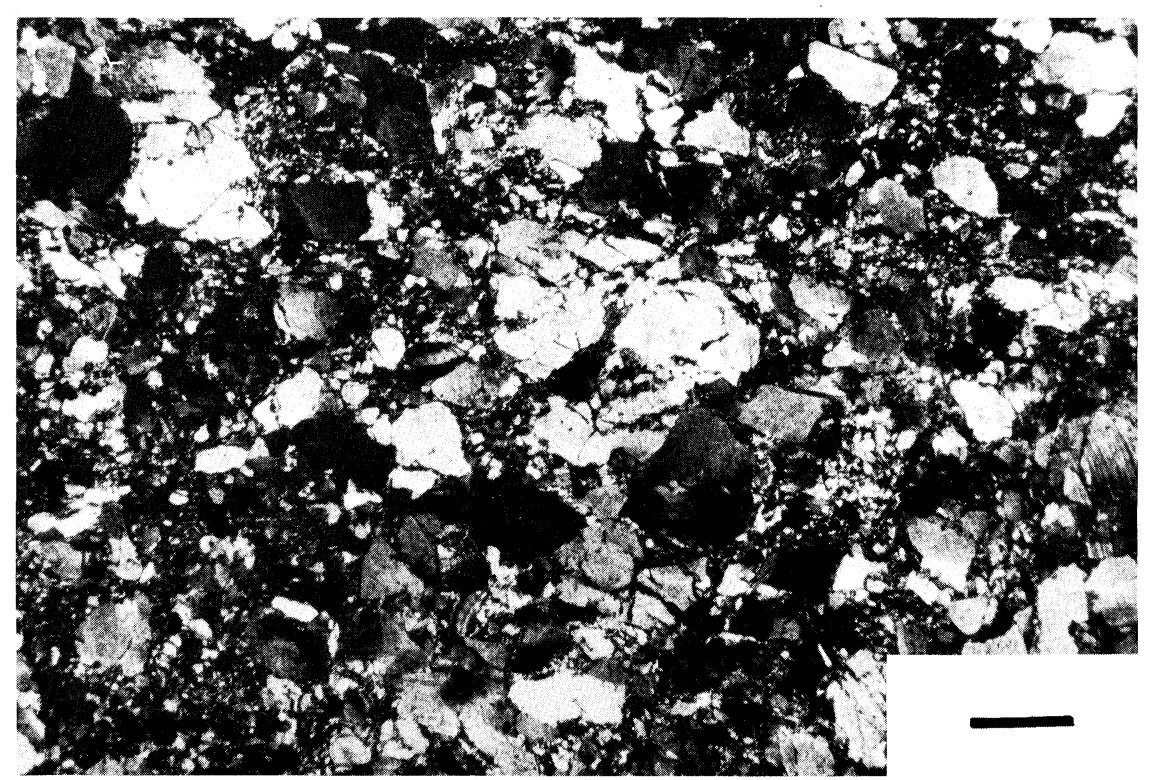

b) 


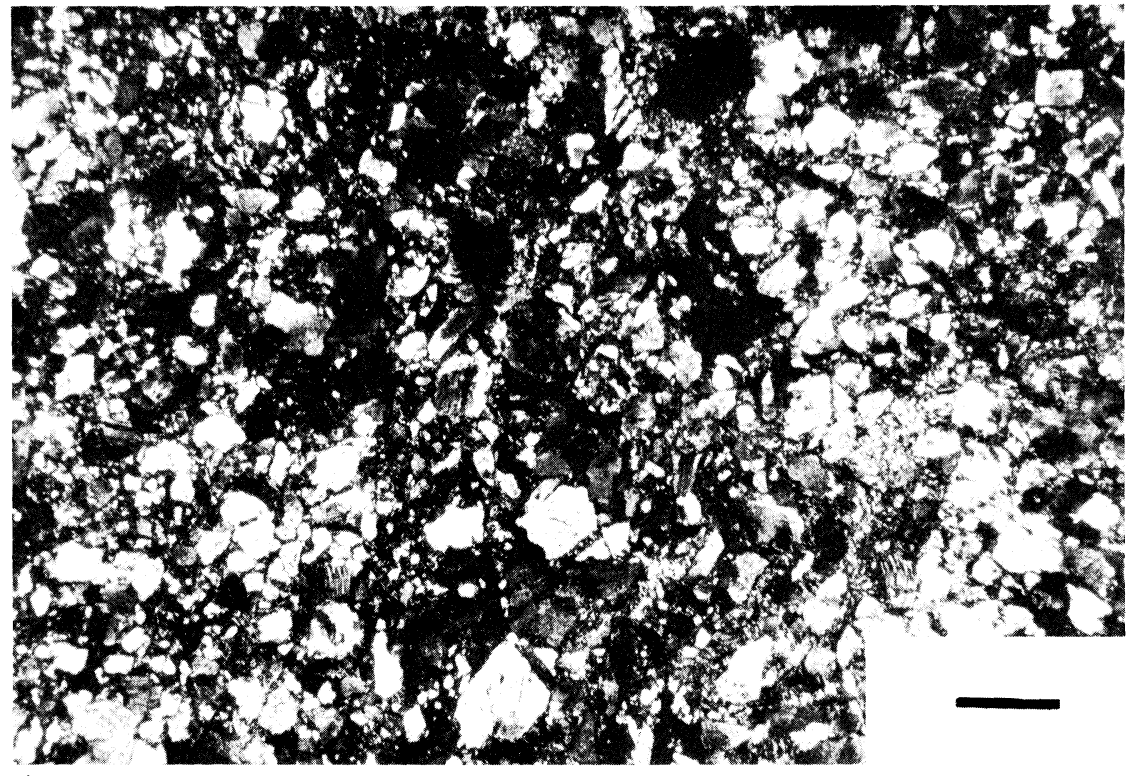

c)

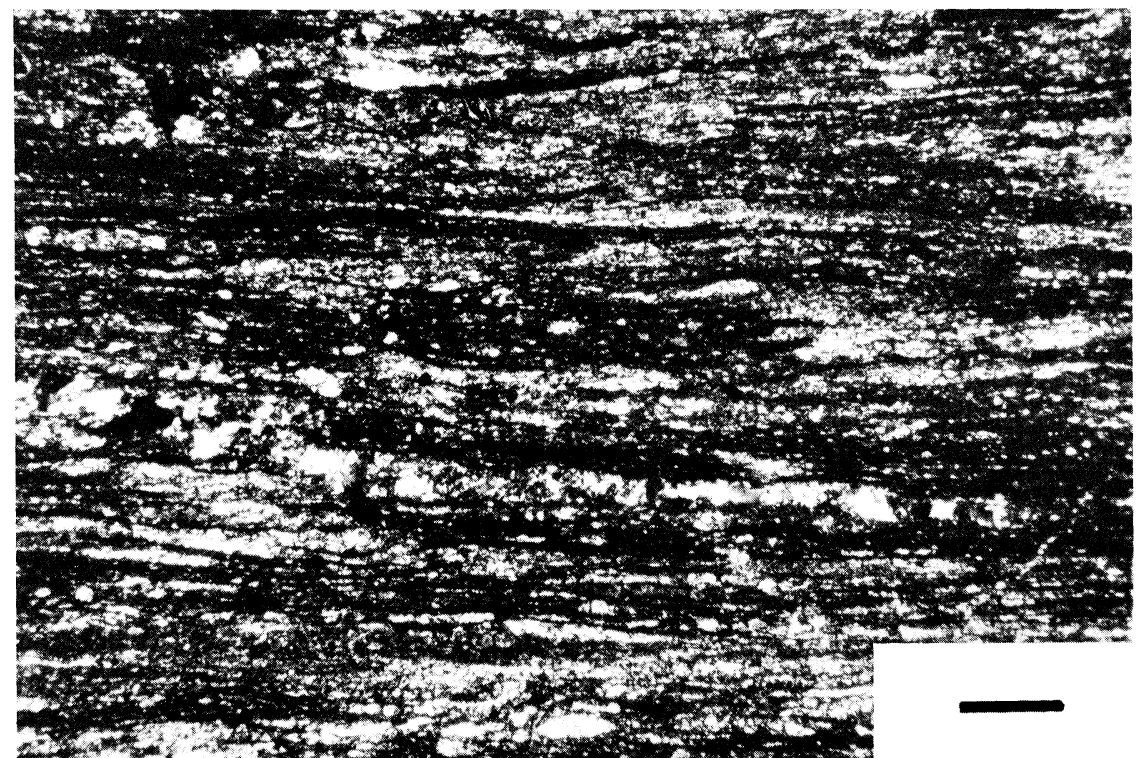

d) 
that these grains also showed evidence of deformation indicating that the recrystallization was syntectonic (dynamic). The continual reduction in the size of the recrystallized grains with increasing shear strain and the maintenance of a constant microstructure in the ultramylonites suggests that continual recrystallization had occurred. This would produce a softening (White et al., 1980). The sharp textures in the Moine ultramylonites are such that the prism and rhomb planes are orientated for easy slip in an $\langle a\rangle$ direction sub-parallel to the foliation (White et al., 1979; Schmid et al., 1981). Although the textures in the Lewisian and Pipe Rock mylonite differ, due to a difference in deformation temperature, nevertheless the texture pattern, in both, is consistent with orientation for slip on the basal and prism planes. These suggest that textural softening was also occurring. Unfortunately, the grain size of the Lewisian ultramylonites and of the recrystallized Pipe Rock grains was too small for optical texture studies. In both of these rocks, deformation at the ultramylonite stage was heterogeneous with deformation, as indicated from a study of the veins, concentrated in the ultrafine grained, mica containing bands. This indicates that a grain size sensitive mechanism was operating i.e. grain boundary sliding (superplasticity) was important in the ultrafine grained bands. These observations also indicate that the deformation and softening mechanisms can change with shear strain.

Feldspars Both the plagioclase and alkali feldspar show evidence for intracrystalline deformation before fracturing, often in a tensile or shear mode, to form a protocataclasite. The mode of tensile fracturing is consistent with fibre loading (see White et al., 1980). The feldspars do not play a major role in the deformation being replaced by secondary minerals which are soft. The alteration first occurs along the fractures and at grain boundaries. The effect of the continual fracturing and alteration is to decrease the size of the clasts and the percentage of feldspar with increasing shear strain. At the ultramylonite stage no feldspar remains and the gneiss has become a quartz phyllosilicate aggregate. The alteration of the feldspars to epidote, muscovite and chlorite involves the release of quartz (see Beach, 1980) thus explaining the increase in quartz relative to the other minerals as the shear strain increases.

The softening of the gneiss, as stated above, is due to the replacement, by mineralogical reactions, of a hard aggregate by one which is soft, i.e. reaction enhanced ductility has occurred. The gneiss also provides a good example of a change in softening processes with increasing shear strain. The main softening mechanism at low shear strains (until the development of the mylonite) was reaction softening. However, as more of the soft minerals were produced and as penetrative bands of the soft phases developed, it is the deformation within these that becomes important. In the Lewisian mylonites 
and ultramylonites (see preceding sub-section) the important mechanisms, in the now mineralogically soft rock, were textural softening, continual recrystallisation, the advent of superplasticity in the ultrafine grained bands.

\section{Brittle deformation at high shear strains}

In all three mylonites and ultramylonites there are quartz veins which are infilled fractures. In the Moine these were undeformed or slightly deformed and appear to have postdated much of the deformation associated with the mylonitisation. However, in the Lewisian and Pipe Rock ultramylonites these veins are extensively deformed. In addition, there are several generations of veins, some being undeformed or little deformed. The veining was therefore not limited to a single event but is the product of many. Furthermore in these quartz rich rocks the veins, after extensive deformation, will become indistinguishable from the matrix and the veining may have been much more extensive than seen at present. In other words, there has probably been a long history of episodic brittle deformation which is now imprinted on the ductile. However, there is no evidence for any work hardening in the microstructures attributed to the ductile deformation suggesting that the brittle occurred as episodic pulses. Seismic activity would explain this. It is now known that much seismic activity is concentrated in the environs of the brittle ductile transition of rocks, that is, at slightly higher crustal levels than the low grade mylonites seen in the Lewisian and Pipe Rock sequences. These ruptures must run into the ductile region at depth and be absorbed by ductile deformation. It is suggested that the veins represent the deformation just above the absorption level but below the level of complete granulation of the rock. In the case of the Moine the fractures were mainly imprinted after mylonitisation, that is probably during uplift.

\section{Preservation of cataclastic microstructures}

In the Lewisian gneisses studied, the cataclastic microstructures survive at low strains but are replaced by foliated mylonites at higher strains. There are two main reasons for this. Firstly, the broken fragments of the feldspar become smeared out, and together with elongated lenses of recrystallized quartz, form a coarse banding. Secondly, and more importantly, the dilation associated with cataclastic fragmentation of hard feldspar allows the ingress of water into the rock to react with the freshly broken surfaces. The main reaction products are the platy minerals muscovite and chlorite which are orientated parallel to the initial c-planes and which enhance the foliation. 
Eventually, as the fragments are consumed by metamorphic reactions, all evidence for the cataclasis is destroyed. However, the metamorphic reactions alone do not destroy the cataclastic microstructure, cataclasis must bring the fragment size down to a minimum. If this was not the case no broken feldspar fragments would be seen even at low shear strains; only pseudomorphs marked by reaction products. It is suggested that the reaction products seal the rock, shutting out the water required for further reactions. The rheological consequences are likely to be dramatic, with a build up of stresses leading to further cataclasis with the ingress of additional water and the cycle being repeated.

The maintenance of a cataclastic microstructure requires that the growth of platy minerals does not occur during deformation or that no phyllosilicates are formed. The latter condition also requires rocks such as pure carbonates or quartzites or that water does not enter the system. If it does, the temperature must be so low that no mineral reactions occur. That is, the preservation of the cataclasite microstructure requires special conditions and will normally be replaced by a foliated mylonite.

\section{Microstructural and textural features indicative of the direction of shearing}

During the course of this study, a number of features were observed that reflected the direction of movement within the individual mylonite zones and which might be used to deduce the direction of movement in zones in which this cannot be done from field criteria. Such features include:

i) asymmetry of intrafolial folds

ii) intersection of shear bands with the mylonite foliation

iii) asymmetry of pressure shadows

iv) rotation of fragments

v) rotation of $c$-axis textures

The relationship of each, apart from (v) to the sense of shearing is sketched in Figure 10. The effect of shearing on the symmetry of the $c$-axis textures can be seen in each of the texture diagrams in Figures 4, 6 and 8, and is discussed in a recent article by Simpson (1980).

The relationship between the asymmetry of the intrafolial folds and shear sense is obvious from Figure 10 and will not be dealt with here. The development of such folds, termed sheath folds (Carreras et al., 1977) has recently been reviewed by Cobbold and Quinquis (1980). Shear bands have been reported in a number of different mylonite types (Watts and Williams, 1979; Platt and Vissers, 1980; White et al., 1980) since attention was first drawn 


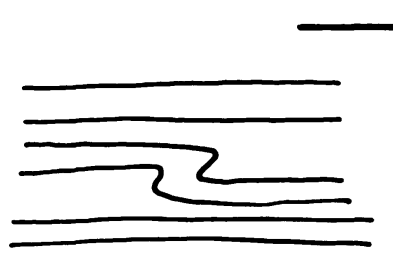

a

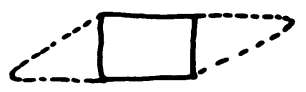

C

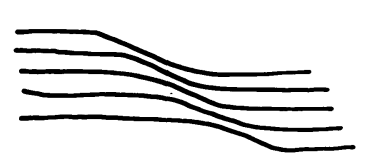

b

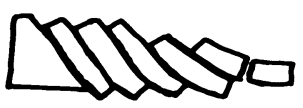

d

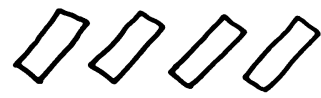

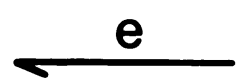

FIGURE 10 A cartoon illustrating the use of microstructural features to determine the sense of shearing in a mylonite zone.

a) Asymmetry of intrafolial folds.

b) Shear bands.

c) Asymmetry of shadow regions associated with hard particles. No fibrous overgrowths were seen in the shadows in the rocks studied. The shadows encountered consisted mainly of equidimensional grains of quartz. Fibrous overgrowths will have the opposite sense of symmetry (see Spry, Figure 57, 1969).

d) Orientation and rotation of fragments produced by shear fractures. They rotate in a direction opposed to shearing and may undergo subsequent tensile fracturing.

e) Rotation of fragments produced by tensile factures.

to their significance in mylonites by White (1979b). They are best developed in phyllosilicate rich mylonites (phyllonites) and are common in the phyllonites in the Eriboll area; their presence is responsible for the oyster or button appearance of these rocks in hand specimen. The shear bands form at a low angle to the mylonite foliation, often giving rise to a non penetrative cross cutting foliation and can accommodate extensional strains within the zone. Platt and Vissers (1980) recently referred to this foliation as an "extensional crenulation cleavage." The orientation of the shear bands, and subsequently the foliation resulting from them, to the sense of shearing has been discussed by White (1979b) and White et al. (1980) and is sketched in Figure 10b.

The effect of the sense of shearing on the shape of pressure shadows containing granular material, cf. quartz in the Lewisian mylonites, is sketched in Figure 10c. It is emphasized that fibrous material in the shadows will produce 
the opposite sense of asymmetry (see Spry, Figure 57, 1969). However, no fibrous shadows were seen in the pressure shadows associated with feldspar fragments in the mylonites studied.

Care must be taken when using rotated fragments to determine the sense of shear. As sketched in Figures 10d and e, fragments arising from shear fracturing rotate in the opposite direction to those formed by tensile fracturing. The former rotate against the shear sense, the latter sympathetic to it. The origin of the fragments must be known before using their sense of rotation to deduce shear sense. This can be done by considering the width of material between fragments; it is narrow in shear fractures and relatively wide in tensile ones (see Figures $2 b$ and $c$ ).

\section{CONCLUSIONS}

The behaviour of a rock during progressive fault rock development is dependent upon its mineralogy. In the rocks studied, those rich in quartz behaved ductilely. Deformation was initially by dislocation creep or warm working mechanisms and grain refinement by dynamic recrystallization. At high shear strains, the deformation mechanism may change to one dominated by grain boundary sliding. The softening mechanisms may also change from continual recrystallization and textural softening to superplasticity.

Rocks rich in feldspar underwent initial grain refinement by cataclasis. Alteration of the feldspars due to the ingress of water during the dilatation associated with fracturing produced mechanically soft minerals which led to the initial concentration of deformation in fault rock zones. However, continuing alteration required continuing cataclasis. The final product is a quartz muscovite chlorite ultramylonite which behaves as a typical quartz-rich ultramylonite. It is concluded that many mylonites and ultramylonites probably began as cataclasites.

All of the mylonites studied contained veins of quartz infilling fractures. In the Lewisian and Pipe Rock ultramylonites, there are several generations of veining and these have tentatively related to episodic seismic activity. Individual veins can be used to study the inhomogeneity of deformation in ultramylonites on the microscale.

\section{Acknowledgements}

Support from NERC (D.E.) and the British Council (D.-L.Z.) is acknowledged. The research was supported by NERC grant GR3/3848. 


\section{References}

Berthe, D., Choukroune, P. and Jegouzo, P. J. Struct. Geol. 1, 31-42 (1979).

Carreras, J., Estrada, A. and White, S. H. Tectonophysics 39, 3-25 (1977).

Cobbold, P. R. and Quinquis, H. J. Struct. Geol. 2, 119-126 (1980).

Lister, G. L. and Hobbs, B. E. J. Struct. Geol. 2, 355-370 (1980).

Platt, J. P. and Vissers, R. L. M. J. Struct. Geol. 2, 397-410.

Schmid, S. M., Casey, M. and Starkey, J. Tectonophysics 78, 101-117 (1981).

Simpson, C. J. Struct. Geol. 2, 243-247 (1980).

Soper, N. J. and Wilkinson, P. Scott. J. Geol. 11, 339-359 (1975).

Teall, J. H. H. Proc. Geol. Ass. 29, 1-15 (1918).

Watts, M. J. and Williams, G. O. J. Struct. Geol. 1, 323-332 (1979).

White, S. Contrib. Mineral. Petrol. 50, 287-304 (1975).

White, S. Phil. Trans. R. Soc. Lond. A283, 69-86 (1976).

White, S. Contrib. Mineral. Petrol. 70, 193-202 (1979a).

White, S. J. Struct. Geol. 1, 333-340 (1979b).

White, S. Textures and Microstructures (in press) (1981).

White, S. H., Burrows, S. E. and Carreras, J. In: Gottstein, G. and Lücke, K. (eds.) Textures of Materials. Springer Verlag, Berlin 2, 211-220 (1979).

White, S. H., Burrows, S. E., Carreras, J., Shaw, N. D. and Humphreys, F. J. J. Struct. Geol. 2, 175-188 (1980). 